\title{
Decadal changes in the mid-depth water mass dynamic of the Northeastern Atlantic margin (Bay of Biscay)
}

\author{
Jean-Carlos Montero-Serrano ${ }^{\mathrm{a}, \mathrm{b}, *}$, Norbert Frank ${ }^{\mathrm{a}, \mathrm{c}}$, Nadine Tisnérat-Laborde $^{\mathrm{a}}$, Christophe Colin ${ }^{\mathrm{b}}$, \\ Chung-Che $\mathrm{Wu}^{\mathrm{d}}{ }, \mathrm{Ke} \mathrm{Lin}^{\mathrm{d}}{ }^{\mathrm{d}}$, Chuan-Chou Shen ${ }^{\mathrm{d}}$, Kevin Copard ${ }^{\mathrm{a}, \mathrm{b}}$, Covadonga Orejas ${ }^{\mathrm{e}}$, Andrea Gori ${ }^{\mathrm{f}}$, \\ Lies De Mol ${ }^{\mathrm{g}}$, David Van Rooij ${ }^{\mathrm{g}}$, Gilles Reverdin ${ }^{\mathrm{h}}$, Eric Douville ${ }^{\mathrm{a}}$ \\ ${ }^{a}$ Laboratoire des Sciences du Climat et de l'Environnement (LSCE/IPSL), UMR-CNRS-CEA-UVSQ Avenue de la Terrasse, 91198 Gif-sur-Yvette Cedex, France \\ ${ }^{\mathrm{b}}$ Laboratoire des Interactions et Dynamique des Environnements de Surface (IDES), UMR-8148, CNRS-Université de Paris-Sud, Bâtiment 504, 91405 Orsay Cedex, France \\ c Institute of Environmental Physics, University of Heidelberg, 69120 Heidelberg, Germany \\ ${ }^{\mathrm{d}}$ High-precision Mass Spectrometry and Environment Change Laboratory (HISPEC), Department of Geosciences, National Taiwan University, Taipei 10617, Taiwan, ROC \\ e Centro Oceanográfico de Baleares, Instituto Español de Oceanografía (IEO), Moll de Ponent s/n, 07015 Palma de Mallorca, Spain \\ ${ }^{\mathrm{f}}$ Institut de Ciències del Mar, Consejo Superior de Investigaciones Científicas (ICM-CSIC), Passeig Maritim de la Barceloneta 37-49, 08003 Barcelona, Spain \\ ${ }^{\mathrm{g}}$ Renard Centre of Marine Geology (RCMG), Department of Geology and Soil Science, Ghent University, Krijgslaan 281 S8, B-9000 Gent, Belgium

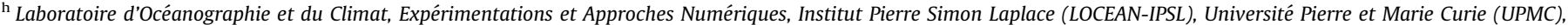 \\ 4 place Jussieu, 75005 Paris, France
}

\section{A R T I C L E I N F O}

\section{Article history:}

Received 19 September 2012

Received in revised form

10 January 2013

Accepted 11 January 2013

Editor: J. Lynch-Stieglitz

Available online 15 February 2013

Keywords:

Northeast Atlantic margin

Bay of Biscay

cold-water coral

trace elements

radiocarbon

neodymium isotopes

\begin{abstract}
A B S T R A C T
The lithium/magnesium ( $\mathrm{Li} / \mathrm{Mg})$ molar ratios, radiocarbon measurements $\left(\Delta^{14} \mathrm{C}\right)$ and $\mathrm{Nd}$-isotopic composition $(\varepsilon N d)$ of the aragonite skeleton of a branching cold-water coral (CWC) species Madrepora oculata collected alive in the Bay of Biscay at $\sim 691 \mathrm{~m}$ water depth were investigated to reconstruct a robust record of the mid-depth water mass dynamics between 1950 and 1990 AD. Temperature estimates based on the skeletons $\mathrm{Li} / \mathrm{Mg}$ molar ratios reveal small decadal changes of about $1{ }^{\circ} \mathrm{C}$ at thermocline depth synchronous to and of similar amplitude as surface temperature anomalies. $\Delta^{14} \mathrm{C}$ measurements shows quasi-decadal oscillations of $15 \%$ around pre-bomb $\Delta^{14} \mathrm{C}$ average value of $-59 \pm 6 \%$ and post-bomb $\Delta{ }^{14} \mathrm{C}$ of $-12 \pm 6 \%$, which most likely reflect decadal changes of water mass exchange across the thermocline. The coral $\varepsilon N d$ values remain in narrow ranges of -11.9 to -10.2 , similar to the isotopic composition of East North Atlantic Central Water, but show highest values in the late 1950s, and early 1960s, 1970s, and 1980s. The punctuated changes of the coral Nd-isotopic composition may thus reflect periods of particular enhanced advection of temperate intermediate water (mid-depth Subpolar Gyre/Mediterranean Sea Water). Altogether, our robust multi-proxy record provides new evidence that Northern Hemisphere atmospheric variability (such as, North Atlantic Oscillation and East Atlantic pattern) drives changes not only in the thermocline but also in the middepth water-mass advection patterns in the Northeastern Atlantic margin. However, the interannual variability of our record remains to be tested.
\end{abstract}

(c) 2013 Elsevier B.V. All rights reserved.

\section{Introduction}

Cold-water corals (CWC hereafter), being widespread ecosystem engineers in water depths between 200 and $2000 \mathrm{~m}$ along the Northeast Atlantic margins (Davies et al., 2008), have been shown to act as useful paleoceanographic archives (see review by Sherwood and Risk (2007)). Their aragonitic skeleton can be accurately dated by means of mass spectrometric ${ }^{230} \mathrm{Th} / \mathrm{U}$ dating

\footnotetext{
* Corresponding author. Present address: Université du Québec à Rimouski, Institut des Sciences de la Mer de Rimouski, 310 allée des Ursulines, Rimouski, QC, Canada G5L 3A1. Tel.: +1 $4187231986 \times 1139$; fax: +1 4187241842 .

E-mail addresses: jeanmontero@yahoo.es,

jeancarlos_monteroserrano@uqar.ca (J.-C. Montero-Serrano).
}

(e.g., Smith et al., 1997; Mangini et al., 1998, Adkins et al., 1998, Cheng et al., 2000; Douville et al., 2010). Several studies have shown that lithium/magnesium ( $\mathrm{Li} / \mathrm{Mg})$ molar ratios, radiocarbon measurements $\left(\Delta^{14} \mathrm{C}\right)$ and neodymium isotopes $(\varepsilon N d)$ of CWCs have the potential to reconstruct rapid changes of temperature (e.g., Montagna et al., 2009; Case et al., 2010), water mass ventilation (e.g., Adkins et al., 1998; Mangini et al., 1998; Frank et al., 2004, 2005; Sherwood et al., 2008) and water mass provenance (e.g., Colin et al., 2010; van de Flierdt et al., 2010; Copard et al., 2010, 2011, 2012; Montero-Serrano et al., 2011; López-Correa et al., 2012), respectively. Therefore, carefully cleaned and accurately dated CWC skeletons allow retrieving the temporal variability of the geochemical composition of water masses (van de Flierdt et al., 2010; Copard et al., 2010). 


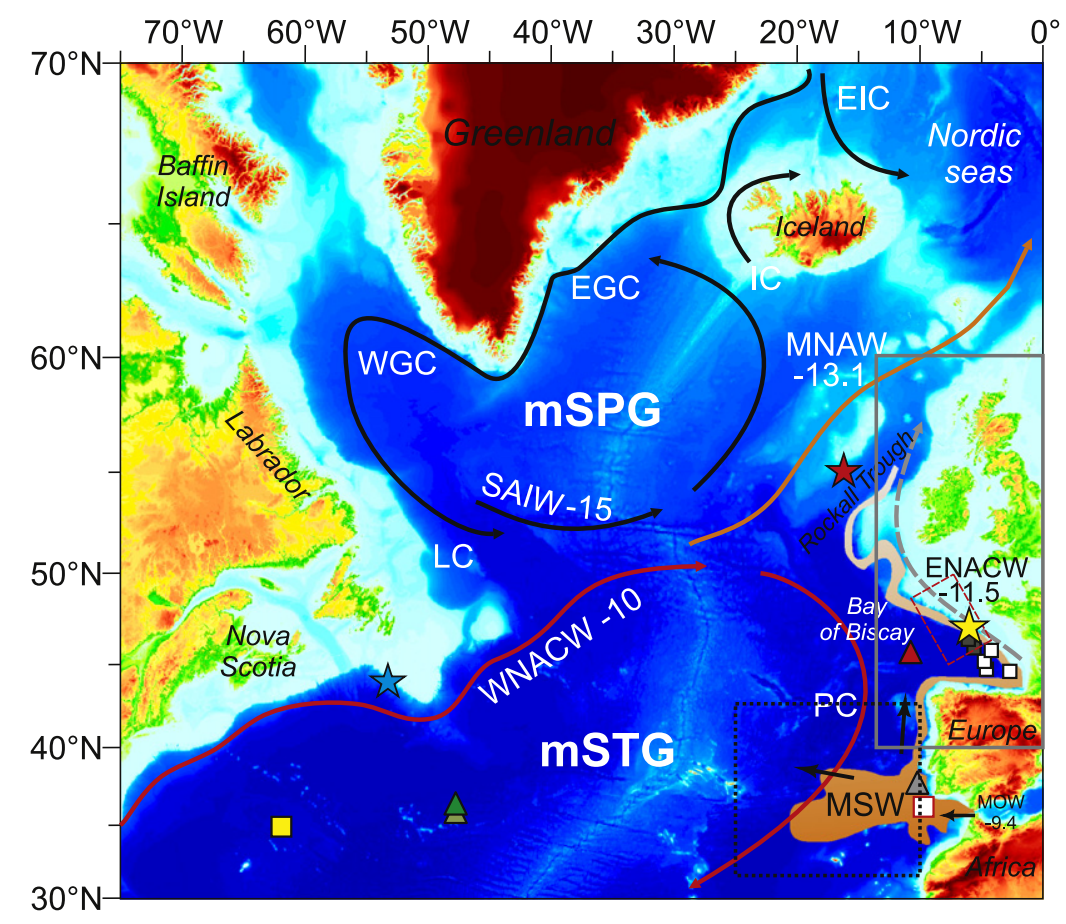

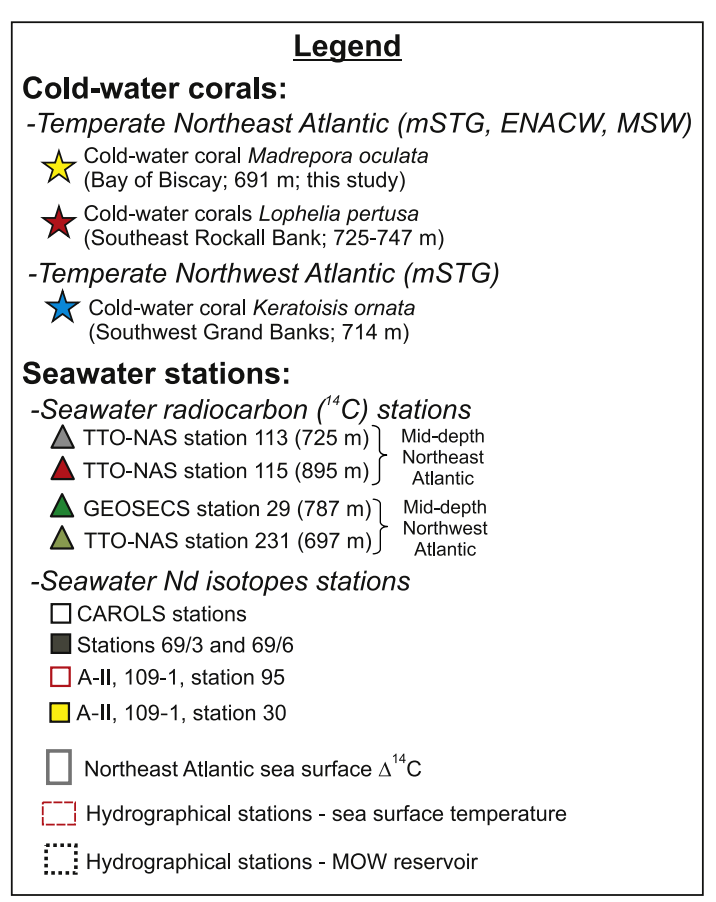

Fig. 1. (Colour online) The modern mid-depth gyres and location of cold-water corals and seawater samples. Cold-water corals: Southwest Grand Banks from Sherwood et al. (2008) and Southeast Rockall Bank from Frank et al. $(2004,2005)$. Seawater radiocarbon $\left({ }^{14} \mathrm{C}\right)$ stations: GEOSECS (Östlund et al., 1974) and TTO-NAS (Broecker et al., 1985). Seawater Nd isotopes stations: A-II 109-1, stations 30 and 95 (Piepgras and Wasserburg, 1983, 1987), CAROLS (Copard et al., 2011), stations 69/3 and 69/6 (Rickli et al., 2009). Northeast Atlantic sea surface $\Delta^{14} \mathrm{C}$ values $\left(40^{\circ}-60^{\circ} \mathrm{N}, 0^{\circ}-14^{\circ} \mathrm{W}\right)$ are from Tisnérat-Laborde (2010). Sea surface temperature stations in the Northeast Atlantic area $\left(46^{\circ}-50^{\circ} \mathrm{N}, 6^{\circ}-12^{\circ} \mathrm{W}\right)$ are from Reverdin et al. (1994). Hydrographical stations from the region west of the Gulf of Cadiz defined as the MOW reservoir $\left(32^{\circ} \mathrm{N}-42^{\circ} \mathrm{N}\right.$, $10^{\circ} \mathrm{W}-25^{\circ} \mathrm{W}$ ) are from Bozec et al. (2011). The main surface and intermediate-water masses of the North Atlantic with their respective $\varepsilon N d$ are also represented (Copard et al., 2010). Water masses are EGC: East Greenland Current; IC: Irminger Current; EIC: East Icelandic Current; ENACW: Eastern North Atlantic Central Water; MNAW: Modified North Atlantic Water; LC: Labrador Current; SAIW: Sub-Arctic Intermediate Water; WNACW: Western North Atlantic Central Water; PC: Portugal Current; MSW: Mediterranean Sea Water; MOW: Mediterranean Outflow Water; mSPG: mid-depth Subpolar Gyre; mSTG: mid-depth Subtropical Gyre.

Two major gyres and an East Atlantic boundary undercurrent characterize the present day mid-depth Northeast Atlantic circulation (e.g., Bower et al., 2002; Hátún et al., 2005; Lozier and Stewart, 2008). Recirculation of water occurs through the cyclonic mid-depth Subpolar Gyre (mSPG) and anticyclonic mid-depth Subtropical Gyre (mSTG) both mixing along the northward cross basin transport underneath the North Atlantic Current (Fig. 1). To the eastern boundary Mediterranean Sea Water (MSW), a mixture mainly of Mediterranean Outflow Water (MOW) and Eastern North Atlantic Central Water (ENACW; a modal water formed by local winter deep convection) flows along the basin boundary contributing salinity to the mid-depth North Atlantic and in particular to the mSTG (e.g., Reid, 1979; Lozier and Stewart, 2008; Fig. 1). Presently, it remains unclear whether MSW contributes directly to the Nordic inflow and feeds salinity also into the mSPG (e.g., Rahmstorf, 1998; McCartney and Mauritzen, 2001; Bower et al., 2002; Dickson et al., 2002; Hátún et al., 2005; Lozier and Stewart, 2008), but it appears that atmospheric circulation changes impact the competition and exchange of those eddy driven mid-depth gyres and the eastern boundary current (e.g., Bower et al., 2002; Lozier and Stewart, 2008; Copard et al., 2012). The atmosphere further impacts the thermocline depth affecting the surface to mid-depth exchange of water, heat and other properties. In fact, little is known about the multidecadal exchange of water across the Northeast Atlantic thermocline and its impact on the heat and salt budget of the North Atlantic Central water (NACW), precursor to the Nordic inflow. Thus, reconstructing the exchange of water across the thermocline and the advection of thermocline water on its way to the north can help to better constrain multi-decadal variability of the North Atlantic mid-depth circulation.
Here we investigated in great detail one branching reef forming CWC collected alive in the Guilvinec Canyon $(\sim 691 \mathrm{~m}$ water depth) of Bay of Biscay that developed during $\sim 40 \mathrm{yr}$ at approximately $100 \mathrm{~m}$ below the mean thermocline depth in the Northeast Atlantic margin. Using high precision mass spectrometry ${ }^{230} \mathrm{Th} / \mathrm{U}$ dating the specimen growth history was determined. Major (Ca) and trace elements ( $\mathrm{Mn}, \mathrm{Li}, \mathrm{Mg}$, and $\mathrm{Nd}$ ), radiocarbon $\left(\Delta^{14} C\right)$ and neodymium isotopes $(\varepsilon N d)$ were measured along the specimens main growth axis to construct a roughly 40-yr long record (1950-1990) of geochemical proxies sensitive to mid-depth mixing and advection processes. To directly compare tracer records with instrumental data, we reconstructed mid-depth temperatures using the $\mathrm{Li} / \mathrm{Mg}$ molar ratio of the CWC aragonite skeleton. The geochemical tracers and the temperature reconstruction obtained on the CWC reveals for the first time decadal variability that is discussed in terms of the recent oscillations of the ocean-atmosphere system.

\section{Material and methods}

\subsection{CWC sample}

A specimen of the CWC species Madrepora oculata (M. oculata hereafter; Fig. 2) about $22 \mathrm{~cm}$ long was sampled in the Guilvinec Canyons $\left(46^{\circ} 54.4^{\prime} \mathrm{N}, 05^{\circ} 19.4^{\prime} \mathrm{W}\right)$ of the Bay of Biscay at $\sim 691 \mathrm{~m}$ water depth between the ENACW and MSW water mass boundaries (De Mol et al., 2011; Copard et al., 2011). In 2008, this coral specimen was sampled alive using the Remotely Operated Vehicle (ROV) 'Genesis' on the R/V Belgica (De Mol et al., 2011), (Fig. 2). The M. oculata coral has a complex branching structure. 
Therefore, successive generations of polyps were sampled along its growth axis, yielding a total of 36 samples from the three major segments identified and having a total length of $18 \mathrm{~cm}$ (Fig. 3a).

\subsection{Analytical procedure}

\subsubsection{Cleaning procedure of the CWC}

The hard parts of CWCs skeletons frequently acquire a black coating of ferromanganese oxides and hydroxides as a consequence of long exposure to seawater. However, the sample investigated here did not present any visible ferromanganese coating and was perfectly preserved given that it was still alive when it was sampled. Rigorous cleaning techniques have however been applied, following the procedure presented by Lomitschka and Mangini (1999) and simplified by Copard et al. (2010), in

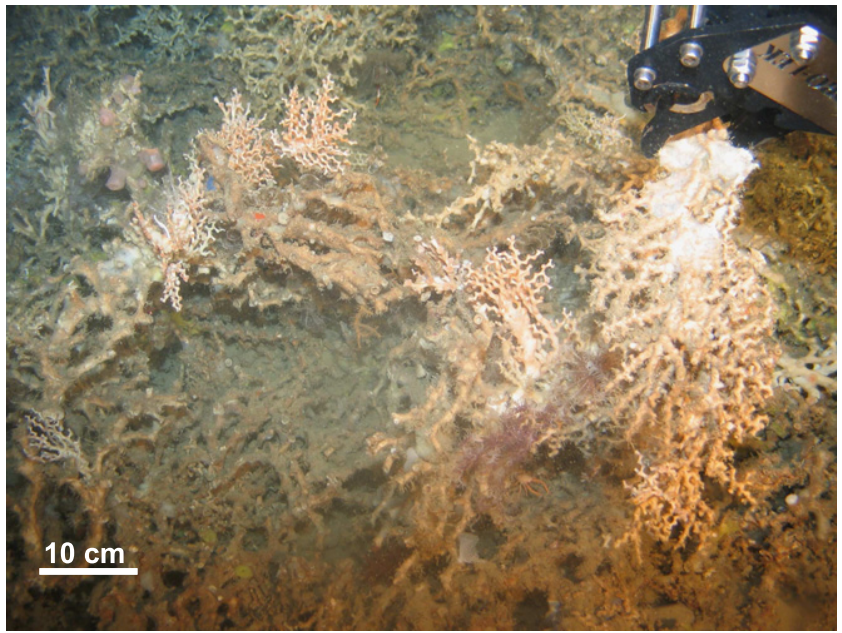

Fig. 2. ROV images, from the south flank of Guilvinec Canyon (Bay of Biscay) in June 2008, highlighting the sampling of M. oculata (B08-04) coral by the ROV at $\sim 691 \mathrm{~m}$ water depth. order to obtain pristine aragonite coral fragments for further geochemical analyses. This procedure consists mainly in carefully polishing the inner and outermost surfaces of the coral skeletons using a diamond-blade saw to retrieve an opaque and translucent pure aragonite skeleton. This mechanical cleaning was followed by two weak attacks with ultraclean $0.5 \mathrm{~N} \mathrm{HCl}$ in an ultrasonic bath for 10 min to remove further potential minor residual Fe-Mn coatings. Additionally, each sample was bathed for $10 \mathrm{~min}$ in peroxide $\left(\mathrm{H}_{2} \mathrm{O}_{2}, 30 \%\right)$ with ultrasonification and subsequently rinsed several times with MilliQ water to remove organic stains left on the coral. After cleaning, coral samples were dried and crushed in an agate mortar in order to obtain a homogeneous powder representative of the average bulk composition of the selected coral fragment.

\subsection{2. ${ }^{230} \mathrm{Th} / \mathrm{U}$ dating}

To create the chronological framework, six samples were collected on the segments 1-3 of the coral: 4 on trunk and 2 on lateral branches for ${ }^{230} \mathrm{Th} / \mathrm{U}$ dating. On average about $\sim 100 \mathrm{mg}$ of cleaned coral powder was used for ${ }^{230} \mathrm{Th} / \mathrm{U}$ dating (Fig. 3a). The analytical work was performed using an inductively coupled plasma multi-collector mass spectrometer (ICP-MC-MS, Thermo Neptune) at the High-precision Mass Spectrometry and Environment Change Laboratory (HISPEC), National Taiwan University (Shen et al., 2012). The chemical methods followed the approaches of Shen et al. (2002, 2003). Procedural blanks are as low as $0.02 \pm 0.01 \mathrm{pmol}{ }^{238} \mathrm{U}, 0.0005 \pm 0.0005 \mathrm{pmol}{ }^{232} \mathrm{Th}$, and $0.0002 \pm 0.0001 \mathrm{fmol}{ }^{230} \mathrm{Th}$. The low ${ }^{230} \mathrm{Th}$ blank corresponds to an age error less than $\pm 0.1 \mathrm{yr}$ for a $0.5 \mathrm{~g}$ late Quaternary coral sample. Offline data reduction and calculations of U-Th isotopic compositions, concentrations, and ${ }^{230} \mathrm{Th} / \mathrm{U}$ age were previously described in Shen et al. (2008).

\subsubsection{Elemental geochemistry}

Cleaned coral samples (20-30 mg each) from the segments 1-3 of the M. oculata coral (Fig. 3a) were dissolved in supra-pure $3 \mathrm{~N} \mathrm{HNO}_{3}$. Ca, $\mathrm{Mn}, \mathrm{Li}, \mathrm{Mg}$ and $\mathrm{Nd}$ concentrations were analyzed a

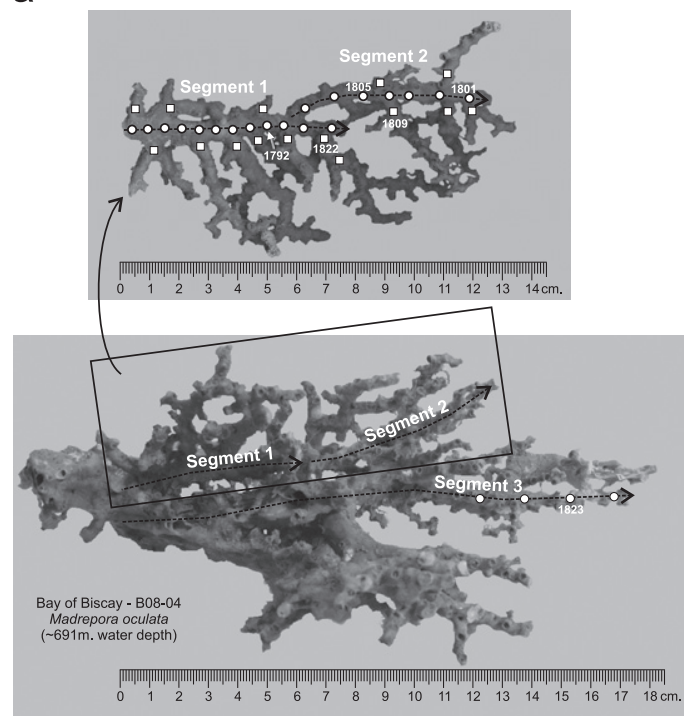

b

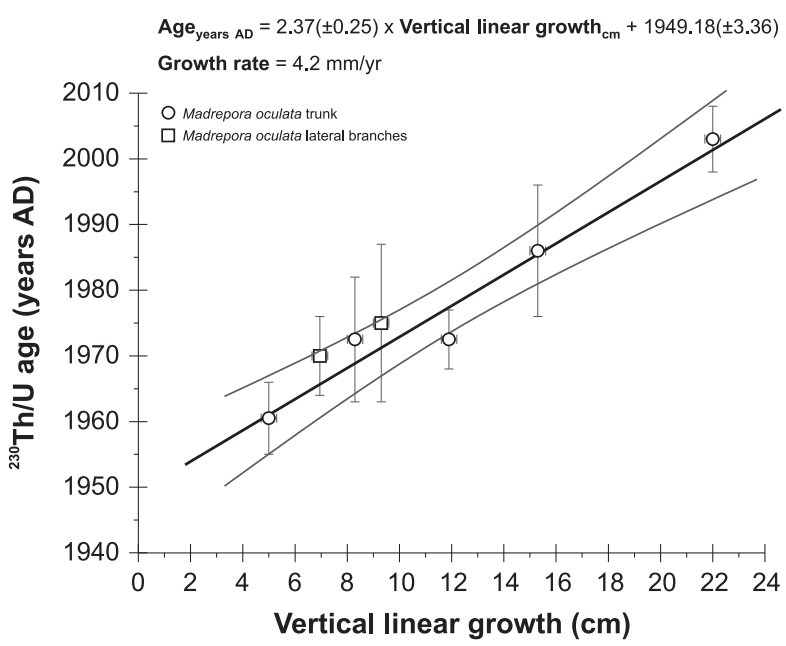

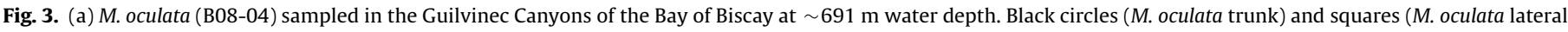

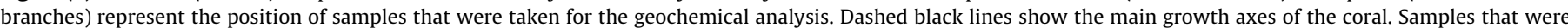

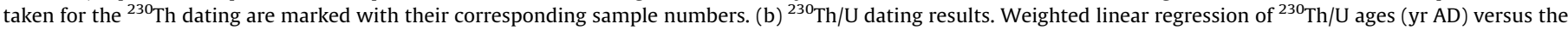

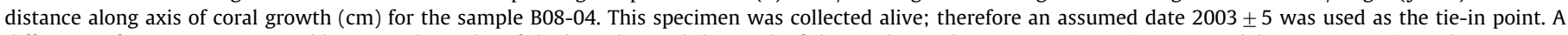

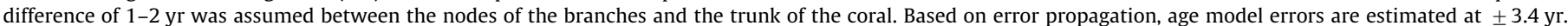
Gray lines represent 95\% confidence intervals. 
using a quadruple ICP-MS Xseries ${ }^{\text {II }}$ (Thermo Fisher Scientific) at the Laboratoire des Sciences du Climat et de l'Environnement (LSCE) by the measurement of their isotopes ${ }^{46} \mathrm{Ca},{ }^{55} \mathrm{Mn},{ }^{7} \mathrm{Li},{ }^{24-25} \mathrm{Mg}$, and ${ }^{146} \mathrm{Nd}$ and by using appropriate external carbonate standards (JCp-1 coral, JCt-1 clam, aragonite AK, calcite BAM 3). Sample and standard solutions have been systematically adjusted at $100 \mathrm{ppm}$ Ca through dilution, without further chemistry (e.g., Harding et al., 2006; Bourdin et al., 2011). To compensate the signal derivation of a few percentage values during a day, a standard (JCp-1) was run every five samples. Instrumental bias was taken into consideration by a bracketing technique giving an analytical uncertainty of $3 \%(2 \sigma)$ for $\mathrm{Li} / \mathrm{Mg}$ molar ratio, $1 \%$ for Ca content and $5 \%$ for $\mathrm{Mn}$ and $\mathrm{Nd}$ concentrations. Procedural blanks are low ( $<0.03 \mathrm{ppm}$ for $\mathrm{Ca}, \mathrm{Mn}$, $\mathrm{Li}$ and $\mathrm{Mg}$, and $<0.1 \mathrm{ppb}$ for $\mathrm{Nd} ; n=65$ ) as compared to the lowest concentration measured in the coral samples. Li/Mg-to-temperature was estimated based on measured $\mathrm{Li} / \mathrm{Mg}$ molar ratios using the following equation (Montagna et al., 2009): Li/Mg $(\mathrm{mmol} / \mathrm{mol})=$ $5.43 \times \mathrm{e}^{\left[-0.049 \pm 0.002 \times T\left({ }^{\circ} \mathrm{C}\right)\right]}$.

\subsubsection{Nd isotopic composition}

About $700 \mathrm{mg}$ of cleaned coral samples from the segments 1-3 of the M. oculata coral (Fig. 3a) was used for the Nd-isotopic measurements by thermal ionization mass spectrometry (TIMS) with an $\mathrm{Nd}$-oxide $\left(\mathrm{NdO}^{+}\right)$technique. The chemical purification of $\mathrm{Nd}$ technique (using TRU-Spec resin and Ln-Spec resin) applied here is described in detail by Copard et al. (2010). Every Nd cut was loaded onto a single tungsten (W) degassed filament and run using $\mathrm{TaF}_{5}$-sandwiches as an ion emitter (Chu et al., 2009). The $\mathrm{TaF}_{5}\left(\mathrm{Ta}-\mathrm{HF}-\mathrm{H}_{3} \mathrm{PO}_{4}\right.$ ) activator solution was prepared and purified using the method outlined by Charlier et al. (2006).

Intensities of ion beams were analysed on a 6 Faraday Collector Finnigan MAT 262 thermal ionization mass spectrometer (LSCE, Gif-sur-Yvette, France) using dynamic multiple collection of metal-oxide masses of 157, 158, 159, 160, 161, 162 and 163 measured in two steps (157-159 and 158-163). Samples were run between 200 and 215 scans with a monitor beam of ${ }^{144} \mathrm{Nd}^{16} \mathrm{O}^{+}$between 300 and $1000 \mathrm{mV}$. Ce and Sm were not found during TIMS measurement. $\mathrm{PrO}^{+}$isobaric interferences were measured and corrected. Nd isotope ratios were corrected for instrumental fractionation relative to ${ }^{146} \mathrm{Nd} /{ }^{144} \mathrm{Nd}=0.7219$ using a power law.

Oxygen isotope ratios were measured statically using ${ }^{150} \mathrm{Nd}$ spike and the same Nd loading technique. The measured oxygen isotopic compositions are ${ }^{18} \mathrm{O} /{ }^{16} \mathrm{O}=0.002004 \pm 0.000026(2 \sigma, n=11)$ and ${ }^{17} \mathrm{O} /{ }^{16} \mathrm{O}=0.000380 \pm 0.000003(2 \sigma, n=11)$. These measured values were used to correct for oxygen isobaric interferences for all isotopes. Concentrations of $\mathrm{Nd}$ in blanks (0.02 ppb; $n=4)$ are negligible as compared to the lowest coral concentration of $7.9 \mathrm{ppb}$. Replicate analyses of $0.5-10 \mathrm{ng}$ the national Rennes $\mathrm{Nd}$ standard, run at ${ }^{144} \mathrm{Nd}^{16} \mathrm{O}^{+}$beam sizes similar to the coral runs, gave a mean ${ }^{143} \mathrm{Nd} /{ }^{144} \mathrm{Nd}$ of $0.511971 \pm 0.000015(2 \sigma, 12$ runs). This mean value matches the certified value of $0.511963 \pm 0.000013$ (Chauvel and Blichert-Toft, 2001). Internal precision was 0.1-0.3 $\varepsilon$ Nd units $\left(2 \sigma_{m}\right)$. In addition, several duplicate analyses of the same coral sample indicate excellent reproducibility within uncertainty of measurement. ${ }^{143} \mathrm{Nd} /{ }^{144} \mathrm{Nd}$ isotopic ratios are expressed as follows: $\varepsilon \mathrm{Nd}=$ $\left(\left[\left({ }^{143} \mathrm{Nd} /{ }^{144} \mathrm{Nd}\right)_{\text {sample }} /\left({ }^{143} \mathrm{Nd} /{ }^{144} \mathrm{Nd}\right)_{\mathrm{CHUR}}\right]-1\right) \times 10000$ (CHUR: Chrondritic Uniform Reservoir; Jacobsen and Wasserburg, 1980).

\subsubsection{Radiocarbon analyses}

To generate radiocarbon time-series, nineteen samples were collected on the segments $1-3$ of the coral (Fig. 3a): 13 on trunk and 7 on lateral branches for radiocarbon analyses. Approximately $15 \mathrm{mg}$ of cleaned powder coral samples was used for radiocarbon $\left({ }^{14} \mathrm{C}\right)$ analyses. Samples were treated with $0.01 \mathrm{~N}$
$\mathrm{HNO}_{3}$ for $15 \mathrm{~min}$, rinsed with pure water, and dried. It was then converted to $\mathrm{CO}_{2}$ in a semi-automated carbonate vacuum line (Tisnérat-Laborde et al., 2001). The $\mathrm{CO}_{2}$ was reduced into graphite using hydrogen in the presence of iron powder (Arnold et al., 1989). Coral samples were analysed using the accelerator mass spectrometry (AMS) facility at ARTEMIS ( $\mathrm{LM}^{14} \mathrm{C}$-Saclay, France). Blanks were obtained on a Lophelia pertusa coral dated $>100,000 \mathrm{yr}$ by the ${ }^{230} \mathrm{Th}$ dating method, and yielded a mean ${ }^{14} \mathrm{C}$ activity $<0.06$ pMC (apparent ${ }^{14} \mathrm{C}$ age $\sim 50,000 \mathrm{yr}$ ). Radiocarbon measurements are reported as conventional ${ }^{14} \mathrm{C}$ ages (in years BP), and $\Delta^{14} \mathrm{C}$ (in \%o) was derived as (Stuiver and Polach, 1977)

$\Delta^{14} \mathrm{C}(\%)=\left(\left(\frac{\mathrm{pMC}(\%)}{100} \times \exp ^{\left(\left(\operatorname{Ln}_{2} / 5730\right) \times\left(1950-\mathrm{Age}_{\mathrm{Th} / U}\right)\right)}\right)-1\right) \times 1000$

All analytical data presented are provided in the Supplementary Appendix A.

\section{Results}

\subsection{Chronological framework: $M$. oculata growth and ${ }^{230} \mathrm{Th} / \mathrm{U}$ dating}

Previous studies have shown that linear growth of $M$. oculata branches is much faster than the one of the main body (or trunk) of the coral (e.g., Orejas et al., 2007, 2011): the coral branches grow more in length and less in diameter, it is the opposite for the coral trunk. This is a frequent pattern in octocoral branched corals already documented in the literature (e.g., Lasker et al., 2003; Cadena and Sánchez, 2010). Thus, based on previous measurements conducted in aquaria and from in-situ coral specimens using different techniques (Orejas et al., 2007, 2011), a difference of 1-2 yr may be assumed between the nodes of the lateral branches and the trunk of the coral. This assumption will be taken into account in the uncertainties concerning the age model (Fig. 3b). The analytical results and the ${ }^{230} \mathrm{Th} / \mathrm{U}$ dates are shown in Table 1 and Fig. 3b. The distance along axis of coral growth $(\mathrm{cm})$ was converted to ${ }^{230} \mathrm{Th} / \mathrm{U}$ age (yr AD) by a weighted linear interpolation between six ${ }^{230} \mathrm{Th} / \mathrm{U}$ ages $(5,6.95,8.3,9.3,11.9$ and $15.3 \mathrm{~cm}$ ) and a tie-in point $(22 \mathrm{~cm}$ ) (Fig. 3b). Linear interpolation from ${ }^{230} \mathrm{Th} / \mathrm{U}$ date suggests that the $M$. oculata coral had a nearly constant linear growth rate of $4.2 \mathrm{~mm} / \mathrm{yr}$ (Fig. 3b). Based on error propagation, age model errors are estimated at $\pm 3.4 \mathrm{yr}$. Thus, the slight age difference (1-2 yr) assumed between the nodes of the branches and the ones of the corals trunk are within the age model uncertainty. The growth rate of $4.2 \mathrm{~mm} / \mathrm{yr}$ for the $M$. oculata coral coincides with the lower values obtained from linear growth measurements performed in aquaria experiments with Mediterranean M. oculata specimens (between 3 and $18 \mathrm{~mm} / \mathrm{yr}$; Orejas et al., 2007, 2011) and are also lower than the one recently measured by ${ }^{210} \mathrm{~Pb}$ on a Norwegian specimen collected at $350 \mathrm{~m}$ depth (11-14 mm/yr; Sabatier et al., 2012). However, the Bay of Biscay is known for its patchy coral occurrences in canyons and along canyon heads. Hence, the rather low growth rate obtained for our M. oculata coral may reflect first evidence of unfavourable environmental growth conditions, which however requires further investigation.

\subsection{Variations in elemental geochemistry, $\Delta^{14} \mathrm{C}$ and $\varepsilon N d$ from the Bay of Biscay CWC}

In Fig. 4, we report the $\mathrm{Mn} / \mathrm{Ca}, \mathrm{Nd} / \mathrm{Ca}$ and $\mathrm{Li} / \mathrm{Mg}$ molar ratios for our coral samples. CWC Nd concentrations in the Bay of Biscay range from 7.9 to $21 \mathrm{ppb}$ (average $12.9 \mathrm{ppb}$ ), similar to those of modern living CWC specimens (6-54 ppb; van de Flierdt et al., 2010; Copard et al., 2010, 2011). Nd/Ca ratios range from 5.1 to 
Table 1

$\mathrm{U}-\mathrm{Th}$ concentrations, isotopic compositions, and ${ }^{230} \mathrm{Th} / \mathrm{U}$ dates of CWC samples (M. oculata).

\begin{tabular}{|c|c|c|c|c|c|c|c|c|c|c|}
\hline Sample ID & $\begin{array}{l}\text { Weight } \\
\text { (g) }\end{array}$ & $\begin{array}{l}{ }^{238} U \\
(\mathbf{p p b})\end{array}$ & $\begin{array}{l}{ }^{232} \mathrm{Th} \\
\text { (ppt) }\end{array}$ & $\begin{array}{l}\delta^{234} U \\
\text { measured }^{\mathrm{a}}\end{array}$ & $\begin{array}{l}\delta^{234} U_{\text {initial }} \\
\text { corrected }^{\text {b }}\end{array}$ & {$\left[{ }^{230} \mathrm{Th} /{ }^{238} \mathrm{U}\right]$ activity ${ }^{\mathrm{c}}$} & {$\left[{ }^{230} \mathrm{Th} /{ }^{232} \mathrm{Th}\right] \mathrm{ppm}^{\mathrm{d}}$} & Age uncorrected & Age corrected ${ }^{c, e}$ & $\begin{array}{l}\text { Age } \\
\text { (yr AD) }\end{array}$ \\
\hline 1792 & 0.1197 & $4686.1 \pm 5.2$ & $298.6 \pm 5.8$ & $141.7 \pm 2.0$ & $141.7 \pm 2.0$ & $0.000574 \pm 0.000011$ & $148.8 \pm 4.1$ & $55.0 \pm 1.1$ & $49.5 \pm 5.5$ & 1960.5 \\
\hline $1822^{*}$ & 0.1030 & $4752.8 \pm 7.3$ & $350.5 \pm 6.8$ & $146.4 \pm 2.3$ & $146.4 \pm 2.3$ & $0.000486 \pm 0.000010$ & $108.8 \pm 3.1$ & $46.3 \pm 1.0$ & $40.0 \pm 6.0$ & 1970 \\
\hline 1801 & 0.0985 & $4358.4 \pm 4.7$ & $247.3 \pm 7.1$ & $142.9 \pm 1.4$ & $142.9 \pm 1.4$ & $0.000443 \pm 0.000011$ & $128.8 \pm 5.0$ & $42.3 \pm 1.1$ & $37.5 \pm 4.5$ & 1972.5 \\
\hline 1805 & 0.1482 & $4257.4 \pm 5.1$ & $575.9 \pm 4.9$ & $144.2 \pm 1.6$ & $144.2 \pm 1.6$ & $0.0005196 \pm 0.0000084$ & $63.4 \pm 1.2$ & $49.6 \pm 0.80$ & $37.5 \pm 9.5$ & 1972.5 \\
\hline $1809^{*}$ & 0.1240 & $4543.7 \pm 6.1$ & $818.4 \pm 5.8$ & $144.8 \pm 2.0$ & $144.9 \pm 2.0$ & $0.000539 \pm 0.000010$ & $49.4 \pm 1.0$ & $51.4 \pm 1.0$ & $35.0 \pm 12$ & 1975 \\
\hline 1823 & 0.0959 & $4226.7 \pm 4.9$ & $574.9 \pm 7.4$ & $143.0 \pm 1.9$ & $143.0 \pm 1.9$ & $0.000381 \pm 0.000012$ & $46.2 \pm 1.6$ & $36.4 \pm 1.2$ & $24.0 \pm 10$ & 1986 \\
\hline
\end{tabular}

Chemistry was performed on June 1st (Shen et al., 2003) and MC-ICP-MS analysis (Shen et al., 2012) on June 9th, 2010.

Analytical errors are $2 \sigma$ of the mean.

a $\delta^{234} U=\left(\left[{ }^{234} U /{ }^{238} U\right]_{\text {activity }}-1\right) \times 1000$.

${ }^{\text {b }} \delta^{234} \mathrm{U}_{\text {initial }}$ corrected was calculated based on ${ }^{230} \mathrm{Th}$ age $(T)$. i.e., $\delta^{234} \mathrm{U}_{\text {initial }}=\delta^{234} \mathrm{U}_{\text {measured }} \times \mathrm{e}^{\lambda 234 \times T}$, and $T$ is corrected age.

${ }^{c}\left[{ }^{230} \mathrm{Th} /{ }^{238} \mathrm{U}\right]_{\text {activity }}=1-\mathrm{e}^{-\lambda 230 T}+\left(\delta^{234} \mathrm{U}_{\text {measured }} / 1000\right)\left[\lambda_{230} /\left(\lambda_{230}-\lambda_{234}\right)\right]\left(1-\mathrm{e}^{-(\lambda 230-\lambda 234) T}\right)$, where $T$ is the age.

Decay constants are $9.1577 \times 10^{-6} \mathrm{yr}^{-1}$ for ${ }^{230} \mathrm{Th}, 2.8263 \times 10^{-6} \mathrm{yr}^{-1}$ for ${ }^{234} \mathrm{U}$ (Cheng et al., 2000) and $1.55125 \times 10^{-10} \mathrm{yr}^{-1}$ for ${ }^{238} \mathrm{U}(\mathrm{Jaffey}$ et al., 1971 ).

${ }^{\mathrm{d}}$ The degree of detrital ${ }^{230} \mathrm{Th}$ contamination is indicated by the $\left[{ }^{230} \mathrm{Th} /{ }^{232} \mathrm{Th}\right]$ atomic ratio instead of the activity ratio.

e Age corrections were calculated using an estimated atomic ${ }^{230} \mathrm{Th} /{ }^{232} \mathrm{Th}$ ratio of $5-30 \mathrm{ppm}$ (Frank et al., 2004).

* M. oculata lateral branches.

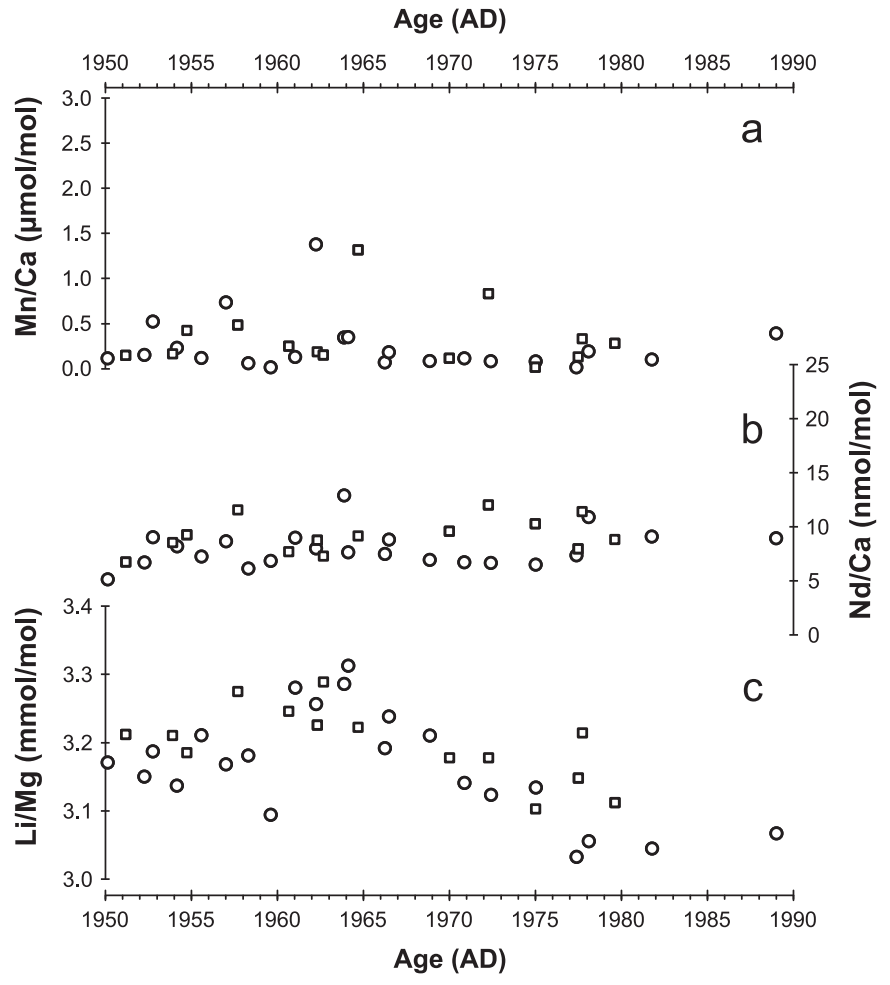

Fig. 4. Variations of $\mathrm{Mn} / \mathrm{Ca}(\mu \mathrm{mol} / \mathrm{mol}), \mathrm{Nd} / \mathrm{Ca}(\mathrm{nmol} / \mathrm{mol})$ and $\mathrm{Li} / \mathrm{Mg}(\mathrm{mmol} / \mathrm{mol})$ ratios through time from the $M$. oculata specimen investigated in this study. The circles and squares represent the samples from the $M$. oculata trunk and branches, respectively.

$12.9 \mathrm{nmol} / \mathrm{mol}$ (average $8.43 \mathrm{nmol} / \mathrm{mol}$ ), $\mathrm{Li} / \mathrm{Mg}$ from 3.03 to $3.31 \mathrm{mmol} / \mathrm{mol}$ (average $3.18 \mathrm{mmol} / \mathrm{mol}$ ), and $\mathrm{Mn} / \mathrm{Ca}$ from 0.02 to $1.38 \mu \mathrm{mol} / \mathrm{mol}$ (average $0.29 \mu \mathrm{mol} / \mathrm{mol}$ ). $\mathrm{Mn} / \mathrm{Ca}$ is not correlated with $\mathrm{Nd} / \mathrm{Ca}$ (correlation coefficient $r^{2}=0.11$ ) and $\mathrm{Li} / \mathrm{Mg}$ (correlation coefficient $r^{2}=0.09$ ), excluding any significant contamination by $\mathrm{Fe}-\mathrm{Mn}$ oxy-hydroxides. In addition, this range in the $\mathrm{Mn} / \mathrm{Ca}$ ratio is comparable with ranges observed in several living CWCs (Copard et al., 2010, 2011). Accordingly, the measured $\mathrm{Nd}$ isotopic compositions and $\mathrm{Li} / \mathrm{Mg}$ molar ratios are representative of ambient seawater conditions.

Subsurface temperatures derived from coral $\mathrm{Li} / \mathrm{Mg}$ ratio range from 10.1 to $11.9{ }^{\circ} \mathrm{C}$ (average $=10.9 \pm 1{ }^{\circ} \mathrm{C}$; error is $2 \sigma$ of the mean), with a minimum between the years 1962 and 1972 AD
(Fig. 7e). The average coral temperature obtained by Li/Mg molar ratio is in agreement, within uncertainty, with the ROV observations at the same water depth $\left(\sim 10.5{ }^{\circ} \mathrm{C}\right.$; De Mol et al., 2011).

The generated $\Delta^{14} \mathrm{C}$ record spans pre- and post-bomb eras for the Bay of Biscay (Fig. 5). Here, all $\Delta{ }^{14} \mathrm{C}$ values are used because no deviation of $\Delta^{14} \mathrm{C}$ was observed between trunk and branches as shown by the comparison between samples GifA-10089 and GifA10100 and samples GifA-10099 and GifA-10106. Our $\Delta^{14} \mathrm{C}$ values are representative of the ones of intermediate water, as indicated by agreement with contemporaneous intermediate water values extracted from nearby TTO-NAS stations 113 and 115 (Fig. 5). The pre-bomb mean value of $\Delta^{14} \mathrm{C}$ is $-59 \pm 6 \%$ corresponding to a reservoir age of $483 \pm 52 \mathrm{yr}$ between 1950 and 1958. After $1958 \pm 2$, the record shows a slight rising of $\Delta^{14} \mathrm{C}$ values due to the input of bomb $\Delta^{14} \mathrm{C}$ in the intermediate water. Then a large rise to 1970 is observed when the value of $-6 \pm 5 \%$ is attained. This value is consistent with Frank et al. (2004) value of $0 \pm 9 \%$ in 1969 (Fig. 5) obtained in a previous study on a Lophelia pertusa collected from down-core ENAM-9915 taken on the Southeast Rockall Bank from $725 \mathrm{~m}$ water depth $\left(55^{\circ} 32^{\prime} \mathrm{N}, 15^{\circ} 40^{\prime} \mathrm{W}\right.$; Fig. 1). After $1970, \Delta^{14} \mathrm{C}$ values continue to slightly rise (post-bomb $\Delta^{14} \mathrm{C}$ average value is $-12 \pm 6 \%$ ). Post-bomb $\Delta{ }^{14} \mathrm{C}$ values also are in close agreement with intermediate seawater values $(-13 \pm 7 \%$ ) reported by Frank et al. $(2004,2005)$ in the Southeast Rockall Bank. Relative to surface waters of Northeast Atlantic (Tisnérat-Laborde et al., 2010; Tisnérat-Laborde, 2010), intermediate water bomb $\Delta^{14} \mathrm{C}$ appeared lagged by $\sim 3 \mathrm{yr}$ and reduced by $\sim 124 \%$ (Fig. 5). Pre-bomb and post-bomb $\Delta{ }^{14} \mathrm{C}$ measurements show also quasi-decadal oscillations of about $15 \%$.

Finally, CWC $\varepsilon N d$ values (average $-11.1 \pm 0.3$ ) shown in Fig. 6 are within ranges of the present-day ENACW $(-11.7 \pm 0.3$; Rickli et al., 2009; Copard et al., 2011) and MSW ( $-11.6 \pm 0.3$; Copard et al., 2011) in the Bay of Biscay. However, four coral samples, dated at 1958, 1962, 1970 and 1985 ( \pm 3.4$)$ yr AD, display slightly more radiogenic $\varepsilon \mathrm{Nd}$ values (up to -10.2 ), suggesting possible slight modifications of seawater $\varepsilon N d$ (Figs. 6 and $7 \mathrm{~g}$ ).

\section{Discussion}

\subsection{Temperature in the Northeastern Atlantic intermediate water}

The robust temperature trends, as derived from the corals $\mathrm{Li} / \mathrm{Mg}$ molar ratio (Fig. 7e), within the Bay of Biscay are in agreement, within uncertainty, with patterns of surface and mid-depth temperature anomaly derived from hydrographical 

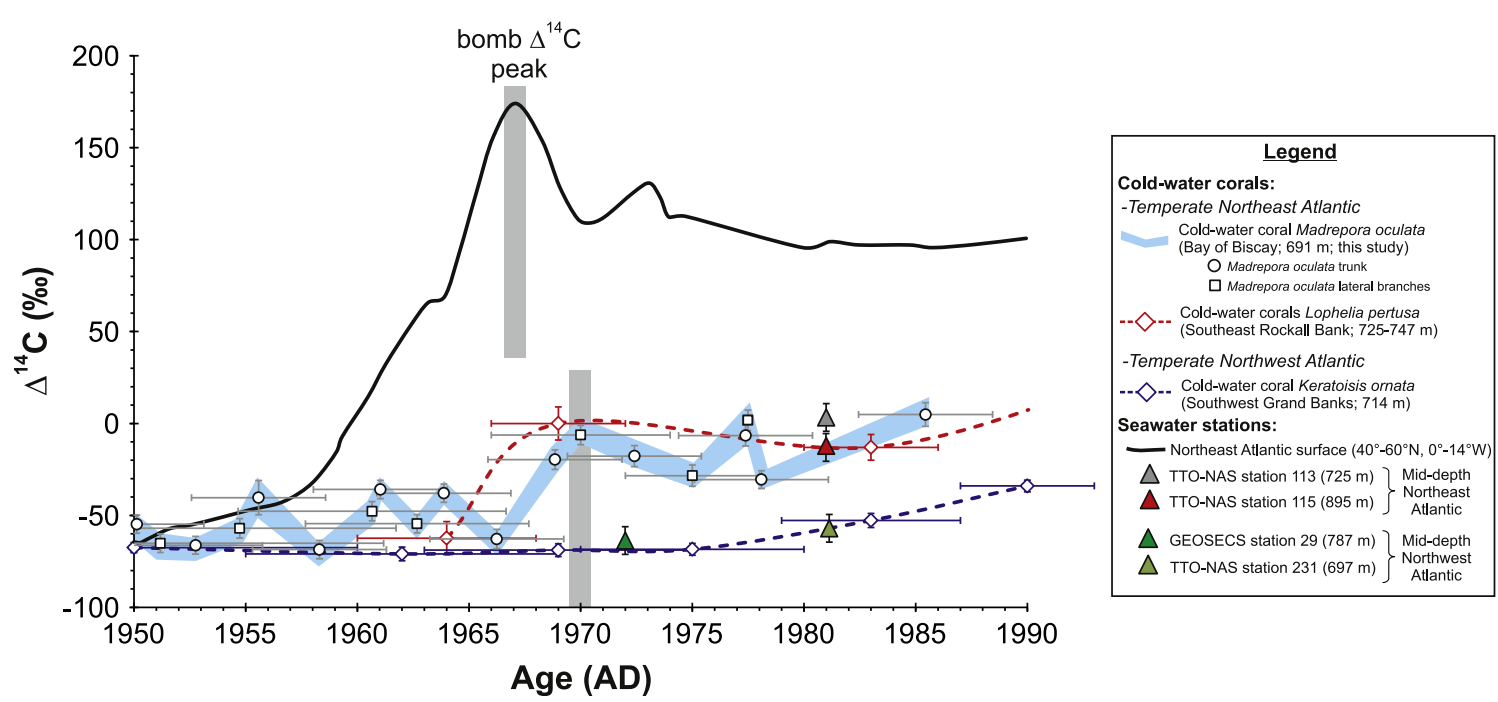

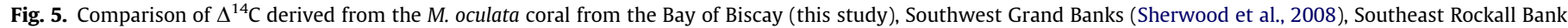

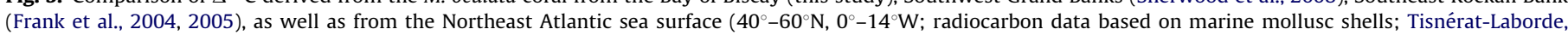

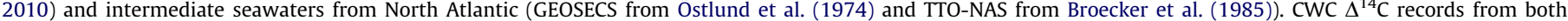

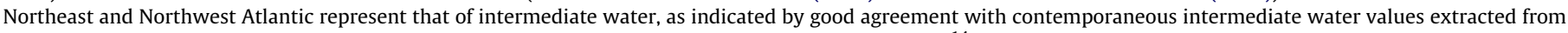

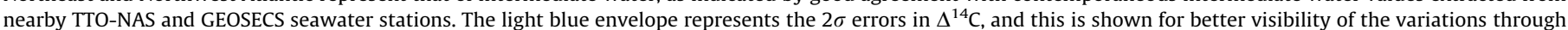

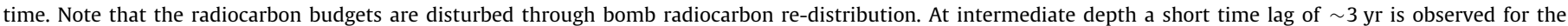

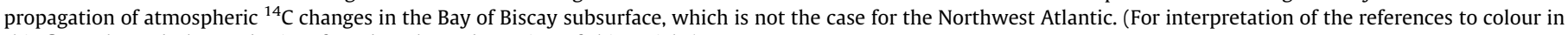
this figure legend, the reader is referred to the web version of this article.)

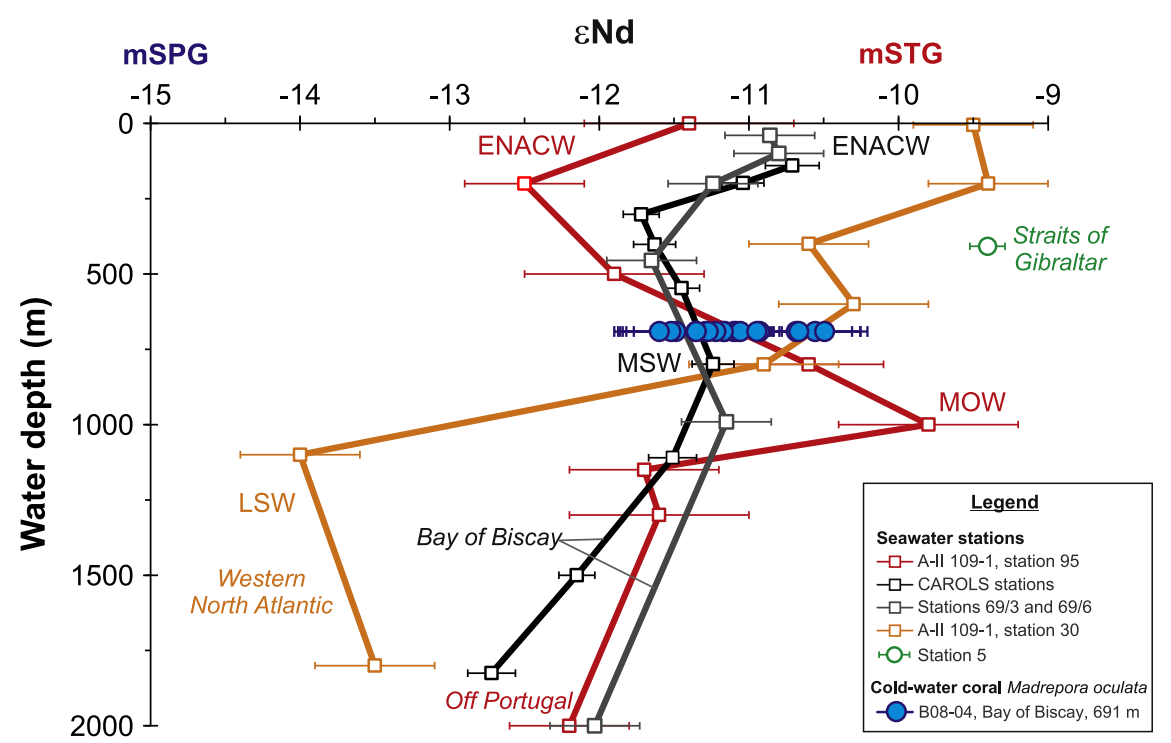

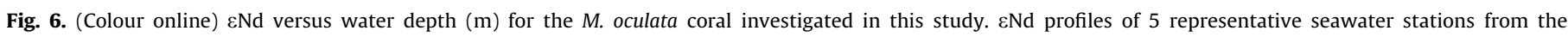

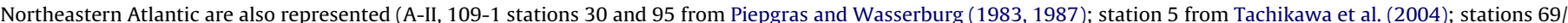

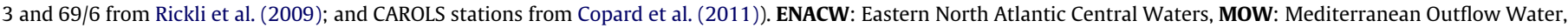
MSW: Mediterranean Sea Water (MOW+ENACW), LSW: Labrador Sea Water.

stations in the Northeast Atlantic margin between 1950 and 1990 (Fig. 7b and c; Reverdin et al., 1994; Potter and Lozier, 2004; Bozec et al., 2011), as well as with the sea surface temperature evolution observed over the whole North Atlantic: a marked cooling until the mid-1960s, followed by a sustained warming over the next $30 \mathrm{yr}$ (e.g., Levitus et al., 2005). This pronounced correlation suggests that $\mathrm{Li} / \mathrm{Mg}$ molar ratios from the analysed CWC of the Bay of Biscay provide a robust signal that reflects small decadal variability of the mid-depth temperature. The drop in subsurface temperature observed between the years 1962 and $1972 \mathrm{AD}$ (Fig. 7e) is likely related to a persistent negative phase of two major modes of atmospheric variability in this region, the North Atlantic Oscillation (NAO; Hurrell and Dickson, 2004) and
East Atlantic pattern (EAP; Josey and Marsh, 2005). The NAO is characterized by a north-south dipole structure with anomalously high/low pressure over the Azores/Iceland, and it modulates the strength and direction of westerly winds and storm tracks across the North Atlantic (Hurrell and Dickson, 2004). The EAP is dominated by a broad region of anomalously low pressure centred at about $\left(55^{\circ} \mathrm{N}, 25^{\circ} \mathrm{W}\right)$ which is approximately midway between the two centres of the NAO dipole (e.g., Josey and Marsh, 2005; Josey et al., 2011). The EAP gives rise to strong cyclonic winds that bring cold air to Arctic and Northern Europe over southern Europe. Hence, the negative NAO/EAP index phase may induce strong heat losses within the Bay of Biscay which reduces the temperature of both surface and subsurface waters in the 
Northeastern Atlantic margin. These interpretations are in agreement with previous studies from the Bay of Biscay performed on the same time period (e.g., Michel et al., 2009a, 2009b; GarciaSoto and Pingree, 2012). In this context, the robust temperature trends, as derived from the corals $\mathrm{Li} / \mathrm{Mg}$ molar ratio, provide clear evidence that the atmospheric processes (such as NAO/EAP) are transferred quickly to intermediate depths ( $\sim 700$ m water depth) along the Northeast Atlantic margin.

\subsection{Seawater $\Delta{ }^{14} C$ and $\varepsilon N d$ variations in the Northeast Atlantic margin}

Radiocarbon content $\left(\Delta^{14} \mathrm{C}\right)$ of dissolved inorganic carbon in seawater is an important tool for constraining oceanic circulation (e.g., Druffel, 1997; Adkins and Boyle, 1997; Mangini et al., 1998; Adkins et al., 2002; Frank et al., 2004, 2005; Robinson et al., 2005; Sherwood et al., 2008; Tisnérat-Laborde et al., 2010). Spatial and temporal variations of the sea surface $\Delta^{14} \mathrm{C}$ reflect wind-driven changes of advection, air-sea gas exchange and vertical convection (e.g., Tisnérat-Laborde et al., 2010). In subsurface seawater, the concentration of ${ }^{14} \mathrm{C}$ is depleted relative to surface because of the isolation from the atmosphere and subsequent ${ }^{14} \mathrm{C}$ decay. Conversely, variations of radiocarbon content $\left(\Delta^{14} C\right)$ in subsurface seawater recorded in CWCs mainly reflect changes in oceanic mixing such as vertical convection and advection of intermediate waters. On the other hand, seawater displays distinct Nd isotopic composition derived primarily from continental weathering, erosion and particle-seawater interactions (e.g., Jeandel et al., 1998; Frank, 2002; Goldstein and Hemming, 2003; Lacan and Jeandel, 2005; Jeandel et al., 2007). Far from any lithogenic source (e.g., dust, river discharge), Nd isotopes are considered to behave quasiconservatively (e.g., Piepgras and Wasserburg, 1987; Tachikawa et al., 2003; Lacan and Jeandel, 2005). Thus, lateral and vertical exchange of water of distinct isotopic composition will cause changes of seawater $\varepsilon N d$ supposing no significant changes of local $\mathrm{Nd}$ isotopic exchange processes (boundary exchange) or local sources (e.g., Jeandel et al., 2007).

Along the Northeast Atlantic margin, water masses have distinct present day $\Delta^{14} \mathrm{C}$ and $\varepsilon N d$ compositions. Today the mSTG waters, originating in the temperate West Atlantic, are poorly ventilated carrying $\Delta^{14} \mathrm{C} \sim-10$ to $-50 \%$ (e.g., Östlund et al., 1974; Broecker et al., 1985) but high $\varepsilon N d$ values from $-9.4 \pm 0.4$ to $-10.3 \pm 0.5$ (Piepgras and Wasserburg, 1987). Within the overlying subtropical waters, the ENACW is characterized by largely higher $\Delta^{14} \mathrm{C}$ values $(\sim+40 \%$; Broecker et al., 1985$)$ but solely slightly lower $\varepsilon N d$ values $(-11.7 \pm 0.3$; Rickli et al., 2009; Copard et al., 2011). Similarly, within the Bay of Biscay, surface waters are characterized by largely higher $\Delta^{14} \mathrm{C}$ values $(\sim+100 \%$; Tisnérat-Laborde, 2010$)$ and slightly lower $\varepsilon N d$ values ( $-10.8 \pm 0.3$; Rickli et al., 2009; Copard et al., 2011). At the exit of the Strait of Gibraltar, the Mediterranean Outflow Water (MOW) is characterized by an $\varepsilon N d$ of $-9.4 \pm 0.2$ (Tachikawa et al., 2004), and is due to rapid overturning in the well ventilated Mediterranean Sea $\left(\Delta^{14} \mathrm{C} \sim+47 \%\right.$; Frank et al., 2010). Along its northward route through the Northeast Atlantic margin, the MOW becomes Mediterranean Sea Water (MSW) which loses its characteristic isotopic composition due to mixing with the ENACW and mSTG. Indeed, at middepth waters off the coast of Iberia and further north in the Bay of Biscay, $\varepsilon N d$ values reach $-10.9 \pm 0.3$ and $-11.2 \pm 0.3$ (Rickli et al., 2009; Copard et al., 2011). Thus, at present, mSTG, MSW, and ENACW cannot be distinguished by their Nd isotopic compositions north of Portugal (Copard et al., 2011). On the contrary, mSPG waters in the Northeast Atlantic margin $\left(\sim 55^{\circ} \mathrm{N}\right)$ carry distinct low $\varepsilon N d$ values $(-14.8 \pm 0.2$; Lacan and Jeandel, 2004) but also relatively high $\Delta{ }^{14} \mathrm{C}$ values $(\sim+20 \pm 5 \%$ today; Nydal and Gislefoss, 1996 ;
Sherwood et al., 2008). Hence, $\varepsilon N d$ may trace sensitive changes of the mid-depth exchange of mSTG and mSPG waters, while $\Delta^{14} \mathrm{C}$ will be most sensitive to either changes of advection of eastern boundary water masses or cross thermocline exchange (e.g., Frank et al., 2004; Tisnérat-Laborde et al., 2010; Colin et al., 2010; Montero-Serrano et al., 2011; Copard et al., 2011, 2012).

\subsubsection{Ventilation changes $\left(\Delta^{14} C\right)$ within the Bay of Biscay}

Pre- and post-bomb $\Delta^{14} \mathrm{C}$ showed quasi-decadal oscillations from -36 to $-65 \%$ and -28 to $5 \%$, respectively (Figs. 5 and 7 f). These oscillations are not synchronous and slightly more frequent compared to variations in the coral $\varepsilon N d$ (Fig. $7 \mathrm{f}-\mathrm{g}$ ), which would be expected if $\Delta^{14} \mathrm{C}$ would be solely driven by a competition of mSPG, mSTG and MSW water masses. Therefore, we hypothesized that another process is recorded by the coral $\Delta{ }^{14} \mathrm{C}$ fluctuations within the Bay of Biscay. In agreement with the mid-depth temperature trends discussed above, this process may be likely related with strong vertical winter mixing between the sea surface and ${ }^{14} \mathrm{C}$-depleted upper intermediate waters in association to atmospheric variability in the North Atlantic (NAO). In fact, strong winter winds at the ocean surface, together with strong heat losses, are responsible for cooling and mixing in typical areas of modal water formation and deep vertical convection (e.g. Marshall et al., 2001). This vertical convection mechanism induces that surface water ${ }^{14} \mathrm{C}$ is exported across the thermocline (as deep as $500 \mathrm{~m}$ water-depth in the Northern Bay of Biscay; Dumousseaud et al., 2010). Likewise, several studies (e.g., Marshall et al., 1993, 2001; Monterey and Levitus, 1997) also suggested that the depth of the mixed layer is deeper in Eastern North Atlantic compared to the Western North Atlantic, which causes stronger mixing between the surface and subsurface water and thus favors the penetration of ${ }^{14} \mathrm{C}$ across the thermocline (Fig. 5). Therefore, we suggest that a southern migration ( $\sim 38-$ $45^{\circ} \mathrm{N}$ ) of enhanced westerlies during times of persistent low atmospheric NAO index (Hurrell and Dickson, 2004) led to stronger vertical mixing within the Bay of Biscay, resulting in a small but significant enrichment in subsurface water $\Delta^{14} \mathrm{C}$. Such scenario is thought to be responsible for the quasi-decadal oscillations in CWC $\Delta^{14} \mathrm{C}$ observed in the mid-depth water mass of the Bay of Biscay (Figs. 5 and 7f). Additionally, the penetration of bomb $\Delta^{14} \mathrm{C}$ into the Bay of Biscay subsurface occurs around the year $1970 \pm 4 \mathrm{AD}$ (reflected by $\sim 53 \%$ change in $\Delta{ }^{14} \mathrm{C}$ ), while the subsurface Western North Atlantic occurs almost a decade later (Fig. 5; Sherwood et al., 2008). This result strongly supports our interpretation that atmospheric processes drive ${ }^{14} \mathrm{C}$ more quickly to thermocline depth in the Eastern North Atlantic compared to the Western North Atlantic (Fig. 5).

\subsubsection{Origin of seawater $\varepsilon N d$ variations within the Bay of Biscay}

Changes in the $\varepsilon N d$ signature of the mid-depth water masses that mix at the water-depth of the ENACW and MSW could be proposed to explain the observed variation in CWC $\varepsilon N d$ (Fig. 6). Indeed, in the mid-depth ocean, the only way to alter the $\mathrm{Nd}$ isotopic composition of water masses is to add Nd with a different isotopic composition through riverine and eolian inputs and boundary exchange or by mixing isotopically different water masses (e.g., Lacan and Jeandel, 2005). However, as discussed by Copard et al. (2011, 2012), we can reasonably assume that the $\varepsilon N d$ values of the Northeastern Atlantic margin sediments have not changed drastically during the last millennium because the sedimentary sources along this margin are characterized by highly similar $\varepsilon N d$ values (Jeandel et al., 2007). In addition, it has also been shown that unradiogenic eolian dust input from North Africa ( $\varepsilon N d-11 \pm 0.4$ to $-14.4 \pm 0.1$; Grousset et al., 1998; Skonieczny et al., 2011) has a negligible contribution to the $\mathrm{Nd}$ 


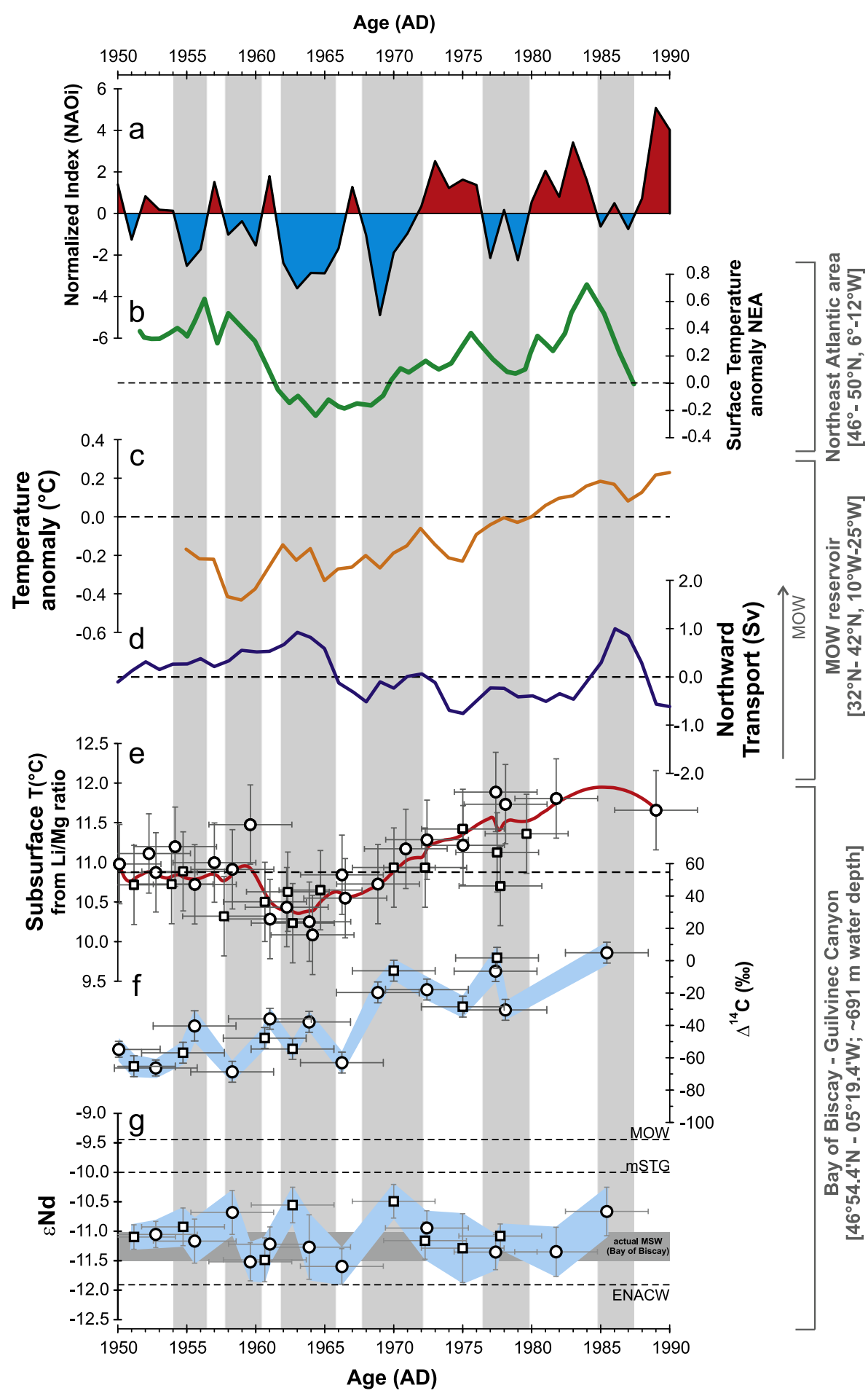

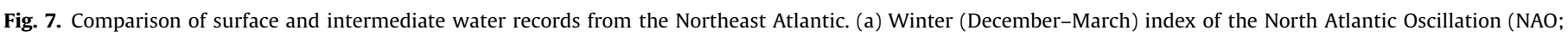

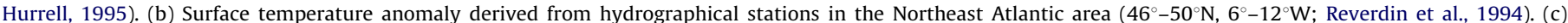

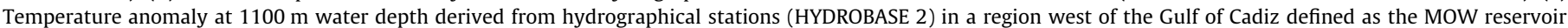

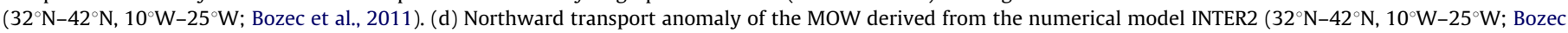

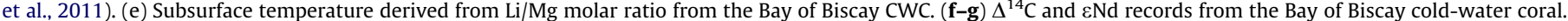

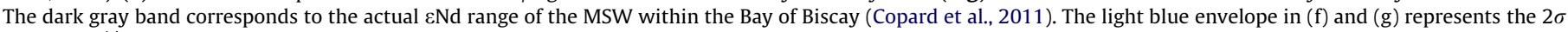

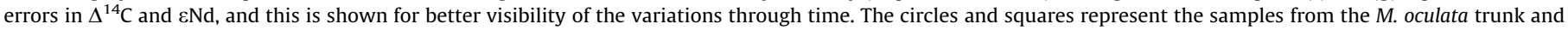
lateral branches, respectively. (For interpretation of the references to colour in this figure legend, the reader is referred to the web version of this article.)

isotopic signature of the intermediate water masses along the Iberian margin (Stumpf et al., 2010, 2011). Consequently, both the boundary exchange of $\mathrm{Nd}$ at the oceanic margin and eolian dust input cannot explain the slightly more radiogenic $\varepsilon N d$ values observed in our CWC specimen. Alternatively, because the surface waters within the Bay of Biscay are slightly more radiogenic $(\varepsilon N d$ $-10.8 \pm 0.3)$ than the middepth waters $(\varepsilon N d-11.6 \pm 0.3)$ (Rickli et al., 2009; Copard et al., 2011), vertical mixing processes might also be responsible for changes in the CWC $\varepsilon N d$ signatures (Fig. 6). However, by performing a simple two end-member mixing 
model, vertical mixing of $\mathrm{Nd}$ isotopic composition between the surface and mid-depth waters within the Bay of Biscay cannot explain the slightly more radiogenic $\varepsilon N d$ values (up to -10.2 ; Fig. 6) observed in our CWC. The same, coral $\varepsilon N d$ variations are not synchronous to trends observed in the coral temperature (derived from Li/Mg molar ratio) and coral $\Delta^{14} \mathrm{C}$ (Fig. 7), which showed a strong interconnection between the surface and subsurface. Therefore, the vertical mixing hypothesis can be discarded to explain the small $\varepsilon N d$ variations observed in our CWC.

Hence, we hypothesized that the slight and robust variations observed in the Bay of Biscay coral $\varepsilon N d$ between 1950 and 1990 (Fig. $7 \mathrm{~g}$ ) may be related mainly to latitudinal modifications of the mid-latitude westerly winds over the North Atlantic (e.g., Hurrell and Dickson, 2004), which in turn have a direct influence on the strength and shape of mSPG, mSTG and MSW circulation (e.g., Lozier and Stewart, 2008; Colin et al., 2010; Häkkinen et al., 2011; Bozec et al., 2011; Montero-Serrano et al., 2011; Copard et al., 2011, 2012). Indeed, during times of persistent low atmospheric NAO index (e.g., 1950-1972 AD; Fig. 7a), a contraction of the mSPG is observed (Lozier and Stewart, 2008), allowing not only a stronger eastward advection of temperate Atlantic mid-depth water masses (mSTG), but also a dominant northward spreading of the MSW (Fig. 7d; Bozec et al., 2011) into the Bay of Biscay. This configuration is thought to be responsible for the moderate increase in seawater $\varepsilon N d$ (up to -10.2 ; Fig. $7 \mathrm{~g}$ ) observed in the mid-depth water mass of the Bay of Biscay at 1958, 1962, 1970 and 1985 years AD. Conversely, during times of persistent high atmospheric NAO index (e.g., 1987-1994 AD; Fig. 7a), the westerlies are displaced northward $\left(\sim 50-55^{\circ} \mathrm{N}\right)$ resulting in a stronger than usual subtropical high-pressure centre and a deeper than normal Icelandic Low (e.g., Hurrell and Dickson, 2004). This scenario promotes both a greater eastward extension of the mSPG (Lozier and Stewart, 2008), which likely affects the hydrology of the Bay of Biscay by limiting the northward advection of temperate Atlantic mid-depth water masses (mSTG/MSW) at those times (Fig. 7d; Bozec et al., 2011), resulting in less radiogenic $\varepsilon N d$ values ( $\sim-11.1$; Fig. $7 \mathrm{~g}$ ) closer to the ones recently measured in seawater. Therefore, changes in the balance and advection of temperate Atlantic mid-depth water masses (mSTG/MSW) along the Northeast Atlantic margin induced by atmospheric forcing may explain the moderate and robust variations in $\varepsilon \mathrm{Nd}$ observed in the Bay of Biscay between 1950 and 1990. Our findings are consistent not only with mid-depth hydrographic data (1950-2000 AD) from the Northeastern Atlantic margin (Lozier and Stewart, 2008), but also with recent North Atlantic and MOW models performed between 1948 and 2006 AD (Häkkinen et al., 2011; Bozec et al., 2011).

\section{Conclusions}

The $\mathrm{Li} / \mathrm{Mg}, \Delta{ }^{14} \mathrm{C}$ and $\varepsilon \mathrm{Nd}$ records of a CWC specimen of $M$. oculata from the Bay of Biscay between 1950 and 1990 presented here are clearly driven by atmospheric forcing (NAO/EAP), with accompanying changes in temperature, ventilation and advection of temperate Atlantic mid-depth water masses (mSTG/MSW) along the Northeast Atlantic margin. The rapid arrival of bomb- ${ }^{14} \mathrm{C}$ in the Bay of Biscay subsurface around the year $1970 \pm 4 \mathrm{AD}$, and the simultaneous drop in surface and subsurface temperature observed between the years 1962 and $1972 \mathrm{AD}$, both related with a persistent negative phase of the NAO and EAP, provide clear evidence that the atmospheric processes are transferred quickly to intermediate depths along the Northeast Atlantic margin. The mismatch between the coral $\varepsilon N d$ and $\Delta{ }^{14} \mathrm{C}$ suggests that $\Delta^{14} \mathrm{C}$ variations within the Bay of Biscay are influenced by strong vertical convection affected by atmospheric forcing, which masks the changes in the lateral advection patterns of intermediate water masses. Furthermore, the moderate and punctuated changes observed in coral $\varepsilon N d$ during times of persistent low atmospheric NAO index likely reflect periods of particularly enhanced advection of temperate intermediate water (mSTG/ MSW) induced by latitudinal modifications of the mid-latitude westerly winds over the North Atlantic. Altogether, our CWC provides a robust record of the mid-depth hydrography within the Bay of Biscay between 1950 and 1990, and confirms the link between atmospheric circulation and intermediate depth ocean observed from hydrographical data and climate simulations (e.g., Lozier and Stewart, 2008; Häkkinen et al., 2011; Bozec et al., 2011). However, because the decadal scale changes of our multiproxy records are quite robust, more synchronous (coeval) records with highly accurate chronologies are required along the Northeastern Atlantic margin to establish more precisely the influence of interannual atmospheric changes on the mid-depth water mass dynamic.

\section{Acknowledgements}

This work was funded through the French Agence National de Recherche projet (NEWTON: ANR-BLANC06-1-139504), the French Centre National de la Recherche Scientifique (CNRS) and the Commisariat à l'Energie Atomique et aux Energies Alternatives (CEA). We also acknowledge Louise Bordier for her support with the ICP-MS analyses. Finally we acknowledge the support of ESF EuroDIVERSITY MiCROSYSTEMS, the EC FP6 IP HERMES (GOCE-CT-2005-511234-1) and EC FP7 IP HERMIONE (Grant agreement no. 226354) projects during which the present coral sample has been recovered. JCMS thanks Norbert Frank, Christophe Colin and Kévin Copard for introducing him to isotope geochemistry. Determinations of $\mathrm{U}-\mathrm{Th}$ isotopic compositions and ${ }^{230} \mathrm{Th} / \mathrm{U}$ dates were supported by Taiwan ROC grants (NSC 1012116-M-002-009 and NTU 102R7625) to C.-C.S. Lastly, thanks to the editor (Jean Lynch-Stieglitz) and the two anonymous reviewers for their very useful comments that allowed improving this manuscript. This is LSCE contribution 5061.

\section{Appendix A. Supplementary material}

Supplementary data associated with this article can be found in the online version at http://dx.doi.org/10.1016/j.epsl.2013.01.012.

\section{References}

Adkins, J.F., Boyle, E.A., 1997. Changing atmospheric Delta C-14 and the record of deep water paleoventilation ages. Paleoceanography 12, 337-344.

Adkins, J.F., Cheng, H., Boyle, E.A., Druffel, E.R.M., Edwards, R.L., 1998. Deep-sea coral evidence for rapid change in ventilation of the deep North Atlantic 15,400 years ago. Science 280, 725-728.

Adkins, J.F., Griffin, S., Kashgarian, M., Cheng, H., Druffel, E.R.M., Boyle, E.A., Edwards, R.L., Shen, C.-C., 2002. Radiocarbon dating of deep-sea corals. Radiocarbon 44, 567-580.

Arnold, M., Bard, E., Maurice, P., Valladas, H., Duplessy, J.C., $1989 .{ }^{14} \mathrm{C}$ dating with the Gifsur-Yvette Tandetron accelerator: status report and study of isotopic fractionation in the sputter ion source. Radiocarbon 31, 284-291.

Bourdin, C., Douville, E., Genty, D., 2011. Alkaline-earth metal and rare-earth element incorporation control by ionic radius and growth rate on a stalagmite from the Chauvet Cave, Southeastern France. Chem. Geol. 290, 1-11.

Bower, A.S., Le Cann, B., Rossby, T., Zenk, W., Gould, J., Speer, K., Richardson, P.L., Prater, M.D., Zhang, H.M., 2002. Directly measured mid-depth circulation in the northeastern North Atlantic Ocean. Nature 419, 603-607.

Bozec, A., Lozier, M.S., Chassignet, E.P., Halliwell, G.R., 2011. On the variability of the Mediterranean outflow water in the North Atlantic from 1948 to 2006 J. Geophys. Res. 116, C09033, http://dx.doi.org/10.1029/2011JC007191.

Broecker, W.S., Peng, T.-H., Ostlund, H.G., Stuiver, M., 1985. The distribution of Bomb Radiocarbon in the Ocean. J. Geophys. Res. 90 (C4), 6953-6970. 
Cadena, N.J., Sánchez, J.A., 2010. Colony growth in the harvested octocoral Pseudopterogorgia acerosa in a Caribbean coral reef. Mar. Ecol. 31, 566-573.

Case, D.H., Robinson, L.F., Auro, M.E., Gagnon, A.C., 2010. Environmental and biological controls on $\mathrm{Mg}$ and $\mathrm{Li}$ in deepsea scleractinian corals. Earth Planet. Sci. Lett. 300, 215-225.

Cheng, H., Adkins, J.F., Edwards, R.L., Boyle, E.A., 2000. U-Th dating of deep-sea corals. Geochim. Cosmochim. Acta 64, 2401-2416.

Colin, C., Frank, N., Copard, K., Douville, E., 2010. Neodymium isotopic composition of deep-sea corals from the NE Atlantic: implications for past hydrological changes during the Holocene. Quat. Sci. Rev. 29, 2509-2517.

Copard, K., Colin, C., Douville, E., Freiwald, A., Gudmundsson, G., De Mol, B., Frank, N., 2010. Nd isotopes in deep-sea corals in the North-eastern Atlantic. Quat. Sci. Rev. 29, 2499-2508.

Copard, K., Colin, C., Frank, N., Jeandel, C., Montero Serrano, J.-C., Reverdin, G. Ferron, B., 2011. Nd isotopic composition of water masses and dilution of the Mediterranean outflow along the South-West European margin. Geochem. Geophys. Geosyst. 12, Q06020, http://dx.doi.org/10.1029/2011GC003529.

Copard, K., Colin, C., Henderson, G.M., Scholten, J., Douville, E., Sicre, M.-A., Frank, N., 2012. Late Holocene intermediate water variability in the northeastern Atlantic as recorded by deep-sea corals. Earth Planet. Sci. Lett. 313-314, 34-44.

Charlier, B.L.A., Ginibre, C., Morgan, D., Nowell, G.M., Pearson, D.G., Davidson, J.P. Ottley, C.J., 2006. Methods for the microsampling and high-precision analysis of strontium and rubidium isotopes at single crystal scale for petrological and geochronological applications. Chem. Geol. 232, 114-133.

Chauvel, C., Blichert-Toft, J., 2001. A hafnium isotope and trace element perspective on melting of the depleted mantle. Earth Planet. Sci. Lett. 190, 137-151.

Chu, Z.Y., Chen, F.K., Yang, Y.H., Guo, J.H., 2009. Precise determination of Sm, Nd concentrations and $\mathrm{Nd}$ isotopic compositions at the nanogram level in geological samples by thermal ionization mass spectrometry. J. Anal. Atom. Spectrom. 24, 1534-1544.

Davies, A.J., Wisshak, M., Orr, J.C., Roberts, J.M., 2008. Predicting suitable habitat for the cold-water coral Lophelia pertusa (Scleractinia). Deep-Sea Res., Part $55,1048-1062$

De Mol, L., van Rooij, D., Pirlet, H., Greinert, J., Frank, N., Quemmerais, F., Henriet, J.-P., 2011. Cold-water coral habitats in the Penmarc'h and Guilvinec Canyons (Bay of Biscay): Deep-water versus shallow-water settings. Mar. Geol. 282, 40-52.

Dickson, B., Yashayaev, I., Meinecke, J., Turrell, B., Dye, S., Holfort, J., 2002. Rapid freshening of the deep North Atlantic Ocean over the past four decades. Nature $416,832-837$.

Douville, E., Salle, E., Frank, N., Eisele, M., Pons-Branchu, E., Ayrault, S., 2010. Rapid and precise ${ }^{230} \mathrm{Th} / \mathrm{U}$ dating of ancient carbonates using Inductively Coupled Plasma-Quadrupole Mass Spectrometry. Chem. Geol. 272, 1-11.

Dumousseaud, C., Achterberg, E.P., Tyrrell, T., Charalampopoulou, A., Schuster, U., Hartman, M., Hydes, D.J., 2010. Contrasting effects of temperature and winter mixing on the seasonal and inter-annual variability of the carbonate system in the Northeast Atlantic Ocean. Biogeosciences 7, 1481-1492.

Druffel, E.R.M., 1997. Pulses of rapid ventilation in the North Atlantic surface ocean during the past century. Science $275,1454-1457$.

Frank, M., 2002. Radiogenic isotopes: tracers of past ocean circulation and erosional input. Rev. Geophys. 40, 1-38.

Frank, N., Paterne, M., Ayliffe, L.K., van Weering, T.C.E., Henriet, J.-P., Blamart, D. 2004. Eastern North Atlantic deep-sea corals: tracing upper intermediate water $\Delta^{14} \mathrm{C}$ during the Holocene. Earth Planet. Sci. Lett. 219, 297-309.

Frank, N., Lutringer, A., Paterne, M., Blamart, D., Henriet, J.P., van Rooij, D., van Weering, T.C.E., 2005. Deep-water corals of the northeastern Atlantic margin carbonate mound evolution and upper intermediate water ventilation during the Holocene. In: Freiwald, A., Roberts, J.M. (Eds.), Cold-Water Corals and Ecosystems, pp. 113-133.

Frank, N., Colin, C., Tisnerat-Laborde, N., Copard, K., Montero-Serrano, J.-C., 2010 The variability of the mid-depth Atlantic re-circulations during the Holocene? In: 10th International Conference on Paleoceanography, Scripps Institution of Oceanography, University of California, La Jolla, California, USA, August 29-September 3rd, 2010.

Garcia-Soto, C., Pingree, R.D., 2012. Atlantic Multidecadal Oscillation (AMO) and sea surface temperature in the Bay of Biscay and adjacent regions. J. Mar. Biol. Assoc. UK 92, 213-234.

Goldstein, S.L., Hemming, S.R., 2003. Long-lived isotopic tracers in oceanography, paleoceanography and ice sheet dynamics. In: Elderfield, H., Holland, H.D. Turekian, K.K. (Eds.), Treatise on Geochemistry, vol. 6, pp. 453-489.

Grousset, F.E., Parra, M., Bory, A., Martinez, P., Bertrand, P., Shimmield, G., Ellam, R.M., 1998. Saharan wind regimes traced by the $\mathrm{Sr}-\mathrm{Nd}$ isotopic composition of subtropical Atlantic sediments: Last Glacial Maximum vs. today. Quat. Sci. Rev. 17, 395-409.

Häkkinen, S., Rhines, P.B., Worthen, D.L., 2011. Warm and saline events embedded in the meridional circulation of the northern North Atlantic. J. Geophys. Res. 116, C03006, http://dx.doi.org/10.1029/2010JC006275.

Harding, D.J., Arden, J.W., Rickaby, R.E.M., 2006. A method for precise analysis of trace element/calcium ratios in carbonate samples using quadrupole inductively coupled plasma mass spectrometry. Geochem. Geophys. Geosyst. 7 (6), http://dx.doi.org/10.1029/2005GC001093.

Hátún, H., Sandø, A.B., Drange, H., Hansen, B., Valdimarsson, H., 2005. Influence of the Atlantic Subpolar Gyre on the thermohaline circulation. Science 309, $1841-1844$.

Hurrell, J.W., 1995. Decadal trends in the North Atlantic Oscillation and relationships to regional temperature and precipitation. Science 269, 676-679.
Hurrell, J.W., Dickson, R.R., 2004. Climate variability over the North Atlantic. In: Stenseth, N.C., Ottersen, G., Hurrell, J.W., Belgrano, A. (Eds.), Marine Ecosystems and Climate Variation the North Atlantic. Oxford University Press.

Jacobsen, S.B., Wasserburg, G.J., 1980. Sm-Nd isotopic evolution of chondrites. Earth Planet. Sci. Lett. 50, 139-155.

Jeandel, C., Thouron, D., Fieux, M., 1998. Concentrations and isotopic compositions of Nd in the Eastern Indian Ocean and Indonesian Straits. Geochim. Cosmochim. Acta 62, 2597-2607.

Jeandel, C., Arsouze, T., Lacan, F., Techine, P., Dutay, J.C., 2007. Isotopic Nd compositions and concentrations of the lithogenic inputs into the ocean: a compilation, with an emphasis on the margins. Chem. Geol. 239, 156-164.

Jaffey, A.H., Flynn, K.F., Glendenin, L.E., Bentley, W.C., Essling, A.M., 1971. Precision measurement of half-lives and specific activities of U-235 and U-238. Phys. Rev. C 4, 1889-1906.

Josey, S.A., Marsh, R., 2005. Surface freshwater flux variability and recent freshening of the North Atlantic in the eastern subpolar gyre. J. Geophys. Res. 110, C05008, http://dx.doi.org/10.1029/2004JC002521.

Josey, S.A., Somot, S., Tsimplis, M., 2011. Impacts of atmospheric modes of variability on Mediterranean Sea surface heat exchange. J. Geophys. Res. 116, C02032, http://dx.doi.org/10.1029/2010JC006685.

Lacan, F., Jeandel, C., 2005. Neodymium isotopes as a new tool for quantifying exchange fluxes at the continentocean interface. Earth Planet. Sci. Lett. 232, 245-257.

Lacan, F., Jeandel, C., 2004. Subpolar Mode Water formation traced by neodymium isotopic composition. Geophys. Res. Lett. 31, L14306.

Lasker, H.R., Boller, M.L., Castanaro, J., Sánchez, J.A., 2003. Determinate growth and modularity in a Gorgonian octocoral. Biol. Bull. 205, 319-330.

Levitus, S., Antonov, J., Boyer, T., 2005. Warming of the world ocean, 1955-2003. Geophys. Res. Lett. 32, L02604, http://dx.doi.org/10.1029/2004GL021592.

Lomitschka, M., Mangini, A., 1999. Precise Th/U-dating of small and heavily coated samples of deep sea corals. Earth Planet. Sci. Lett. 170, 391-401.

López-Correa, M., Montagna, P., Joseph, N., Rüggeberg, A., Fietzke, J., Flögel, S., Dorschel, B., Goldstein, S.L., Wheeler, A., Freiwald, A., 2012. Preboreal onset of Norwegian cold-water coral growth beyond the Arctic Circle revealed by radiocarbon and U-series dating and neodymium isotopes. Quat. Sci. Rev. 34, 24-43.

Lozier, M.S., Stewart, N.M., 2008. On the temporally varying northward penetration of Mediterranean overflow water and eastward penetration of Labrador Sea water. J. Phys. Oceanogr. 38, 2097-2103.

Mangini, A., Lomitschka, M., Eichstadter, R., Frank, N., Vogler, S., 1998. Coral provides way to age deep water. Nature 392, 347-348.

Marshall, J.C., Nurser, A.J.G., Williams, R.G., 1993. Inferring the subduction rate and period over the North Atlantic. J. Phys. Oceanogr. 23, 1315-1329.

Marshall, J., Johnson, H., Goodman, J., 2001. Interaction of the North Atlantic Oscillation with ocean circulation. J. Clim. 14, 1399-1421.

McCartney, M.S., Mauritzen, C., 2001. On the origin of the warm inflow to the Nordic Seas. Prog. Oceanogr. 51, 125-214.

Michel, S., Treguier, A.M., Vandermeirsch, F., 2009a. Temperature variability in the Bay of Biscay during the past 40 years, from an in situ analysis and a 3D global simulation. Cont. Shelf Res. 29, 1070-1087.

Michel, S., Vandermeirsch, F., Lorance, P., 2009b. Evolution of upper layer temperature in the Bay of Biscay during the last 40 years. Aquat. Living Resour. 22, 447-461.

Montagna, P., López-Correa, M., Rüggeberg, A., McCulloch, M., Rodolfo-Metalpa, R. Ferrier-Pagès, C., Freiwald, A., Goldstein, S., Henderson, G., Mazzoli, C., Russo, S., Silenzi, S., Taviani, M., Trotter, J., 2009. Li/Mg ratios in shallow and deep-sea coral exoskeleton as a new temperature proxy. AGU Fall Meeting, December 14-18, 2009, San Francisco, USA.

Montero-Serrano, J.C., Frank, N., Colin, C., Wienberg, C., Eisele, M., 2011. The climate influence on the mid-depth Northeast Atlantic gyres viewed by cold-water corals. Geophys. Res. Lett. 38, L19604, http://dx.doi.org/10.1029/2011GL048733.

Monterey, G.I., Levitus, S., 1997. Climatological Cycle of Mixed Layer Depth in the World Ocean. US Government Printing Office, NOAA NESDIS, p. 5

Nydal, R., Gislefoss, J.S., 1996. Further application of bomb ${ }^{14} \mathrm{C}$ as a tracer in the atmosphere and ocean. Radiocarbon 38, 389-406.

Östlund, G.H., Dorsey, H.G., Rooth, C.G.H., 1974. GEOSECS North Atlantic radiocarbon and tritium results. Earth Planet. Sci. Lett. 23, 69-86.

Orejas, C., Gori, A., Gili, J.M., 2007. Growth rates of live Lophelia pertusa and Madrepora oculata from the Mediterranean Sea maintained in aquaria. Coral Reefs 27, 255

Orejas, C., Ferrier-Pagès, C., Reynaud, S., Gori, A., Beraud, E., Tsounis, G., Allemand, D., Gili, J.M. 2011. Long-term growth rate measurements of four Mediterranean cold water coral species (Madrepora oculata, Lophelia pertusa, Desmophyllum dianthus and Dendrophyllia cornigera) maintained in aquaria. Mar. Ecol. Prog. Ser. 429, 57-65.

Piepgras, D.J., Wasserburg, G.J., 1983. Influence of the Mediterranean outflow on the isotopic composition of Neodymium in waters of the North Atlantic. J. Geophys. Res. 88, 5997-6006.

Piepgras, D.J., Wasserburg, G.J., 1987. Rare earth element transport in the western North Atlantic inferred from Nd isotopic observations. Geochim. Cosmochim. Acta 51, 1257-1271.

Potter, R.A., Lozier, M.S., 2004. On the warming and salinification of the Mediterranean outflow waters in the North Atlantic. Geophys. Res. Lett. 31, L01202, http://dx.doi.org/10.1029/2003GL018161.

Rahmstorf, S., 1998. Influence of Mediterranean outflow on climate: EOS (Transactions, American Geophysical Union), 79, 281-282.

Reid, J.L., 1979. On the contribution of the Mediterranean Sea outflow to the Norwegian-Greenland Sea. Deep-Sea Res.-Part A, Oceanogr. Res. 26, $1199-1223$. 
Reverdin, G., Cayan, D., Dooley, H.D., Ellett, D.J., Levitus, S., Du Penhoat, Y., Dessier, A., 1994. Surface salinity of the North Atlantic: can we reconstruc its fluctuations over the last one hundred years? Prog. Oceanogr. 33, 303-346.

Rickli, J., Frank, M., Halliday, A.N., 2009. The hafnium-neodymium isotopic composition of Atlantic seawater. Earth Planet. Sci. Lett. 280, 118-127.

Robinson, L.F., Adkins, J.F., Keigwin, L.D., Southon, J., Fernandez, D.P., Wang, S.-L. Scheirer, D.S., 2005. Radiocarbon variability in the Western North Atlantic during the last deglaciation. Science 310, 1469-1473.

Sabatier, P., Reyss, J.-L., Hall-Spencer, J.M., Colin, C., Frank, N., Tisnérat-Laborde, N. Bordier, L., Douville, E., 2012. ${ }^{210} \mathrm{~Pb}-{ }^{226} \mathrm{Ra}$ chronology reveals rapid growth rate of Madrepora oculata and Lophelia pertusa on world's largest cold-water coral reef. Biogeosciences 9, 1253-1265.

Skonieczny, C., Bory, A., Bout-Roumazeilles, V., Abouchami, W., Galer, S.J.G., Crosta, X., Stuut, J.B., Meyer, I., Chiapello, I., Podvin, T., Chatenet, B., Diallo, A., Ndiaye, T., 2011. The 7-13 March 2006 major Saharan outbreak: multi-proxy characterization of mineral dust deposited on the West African margin. J. Geophys. Res. 116, D18210.

Shen, C.-C., Edwards, R.L., Cheng, H., Dorale, J.A., Thomas, R.B., Moran, S.B. Weinstein, S.E., 2002. Uranium and thorium isotopic and concentration measurements by magnetic sector inductively coupled plasma mass spectrometry. Chem. Geol. 185, 165-178.

Shen, C.-C., Cheng, H., Edwards, R.L., Moran, S.B., Edmonds, H.N., Hoff, J.A., Thomas, R.B., 2003. Measurement of attogram quantities of ${ }^{231} \mathrm{~Pa}$ in dissolved and particulate fractions of seawater by isotope dilution thermal ionization mass spectroscopy. Anal. Chem. 75, 1075-1079.

Shen, C.-C., Li, K.-S., Sieh, K., Natawidjaja, D., Cheng, H., Wang, X., Edwards, R.L., Lam, D.D., Hsieh, Y.-T., Fan, T.-Y., Meltzner, A.J., Taylor, F.W., Quinn, T.M. Chiang, H.-W., Kilbourne, K.H., 2008. Variation of initial ${ }^{230} \mathrm{Th} /{ }^{232} \mathrm{Th}$ and limits of high precision U-Th dating of shallow-water corals. Geochim. Cosmochim. Acta 72, 4201-4223.

Shen, C.-C., Wu, C.-C., Cheng, H., Edwards, R.L., Hsieh, Y.-T., Gallet, S., Chang, C.-C., Li, T.-Y., Lam, D.D., Kano, A., Hori, M., Spötl, C., 2012. High-precision and highresolution carbonate ${ }^{230}$ Th dating by MC-ICP-MS with SEM protocols. Geochim. Cosmochim. Acta 99, 71-86.

Sherwood, O.A., Edinger, E.N., Guilderson, T.P., Ghaleb, B., Risk, M., Scott, D.B., 2008. Late Holocene radiocarbon variability in Northwest Atlantic slope waters. Earth Planet. Sci. Lett. 275, 146-153.
Sherwood, O.A., Risk, M., 2007. Deep-sea corals: new insights to paleoceanography. In: Hillaire-Marcel, C., deVernal, A. (Eds.), Proxies in Late Cenozoic Paleoceanography. Developments in Marine Geology 1, pp. 491-522.

Smith, J.E., Risk, M.J., Schwarcz, H.P., McConnaughey, T.A., 1997. Rapid climate change in the North Atlantic during the Younger Dryas recorded by deep-sea corals. Nature 386, 818-820.

Stumpf, R., Frank, M., Schönfeld, J., Haley, B.A., 2010. Late Quaternary variability of Mediterranean Outflow Water from radiogenic Nd and Pb isotopes. Quat. Sci. Rev. 29, 2462-2472.

Stumpf, R., Frank, M., Schönfeld, J., Haley, B.A., 2011. Climatically driven changes in sediment supply on the SW Iberian shelf since the Last Glacial Maximum. Earth Planet. Sci. Lett. 312, 80-90.

Stuiver, M., Polach, H.A., 1977. Discussion reporting of ${ }^{14} \mathrm{C}$ data. Radiocarbon 19 (3), 355-363.

Tachikawa, K., Athias, V., Jeandel, C., 2003. Neodymium budget in the modern ocean and paleooceanographic implications. J. Geophys. Res. 108 (C8), 3254, http://dx.doi.org/10.1029/1999JC000285.

Tachikawa, K., Roy-Barman, M., Michard, A., Thouron, D., Yeghicheyan, D., Jeandel, C. 2004. Neodymium isotopes in the Mediterranean Sea: comparison between seawater and sediment signals. Geochim. Cosmochim. Acta 68, 3095-3106.

Tisnérat-Laborde, N., Poupeau, J.-J., Tannau, J.-F., Paterne, M., 2001. Development of a semi-automated system for routine preparation of carbonate sample. Radiocarbon 43 (2A), 299-304.

Tisnérat-Laborde, N., Paterne, M., Métivier, B., Arnold, M., Yiou, P., Blamart, D. Raynaud, S., 2010. Variability of the northeast Atlantic sea surface $\Delta^{14} \mathrm{C}$ and marine reservoir age and the North Atlantic Oscillation (NAO). Quat. Sci. Rev. 29, 2633-2646.

Tisnérat-Laborde, N., 2010. Variation du $\Delta{ }^{14} \mathrm{C}$ dans l'océan de surface de l'Atlantique Nord-est au cours des 200 dernières années. Ph.D. Thesis, Université Paris-Sud XI, Orsay, France, p. 189.

van de Flierdt, T., Robinson, L.F., Adkins, J.F., 2010. Deep-sea corals aragonite as a recorder for the neodymium isotopic composition of seawater. Geochim. Cosmochim. Acta 74, 6014-6032. 